\title{
España, la nación que no existe
}

\section{Spain, the Nation that doesn't Exist}

\author{
Félix DuQue \\ Universidad Autónoma de Madrid \\ felixduque@telefonica.net
}

Recibido: 05/09/2013

Aceptado: 20/02/2014

\section{Resumen}

El difícil problema, no resuelto por el siglo XIX español, y que hoy ha llegado a un punto muerto (a pesar del derramamiento de sangre de nuestros compatriotas en la Guerra Civil), gira en torno a la cuestión de si España es una nación en el sentido liberal, es decir, una comunidad soberana, con un sistema político representativo y una forma de autonomía gubernamental, sostenida por la voluntad de sus miembros, protegidos por una ley común que los atañe aun sin haber sido responsables de su formulación, o si por el contrario es una nacionalidad en el viejo sentido griego, hasta cierto punto similar a una Ciudad (pólis): un organismo vivo, un proceso de crecimiento y muerte interno a la lenta formación histórica de un pueblo ligado a un territorio, con un lenguaje común y tradiciones y costumbres compartidas.

Palabras clave: Nación, nacionalidad, país, Constitución, liberalismo, organicismo.

\section{Abstract}

The difficult question, that has not been answered by the 19th Century in Spain, and that has arrived at a deadlock until today (despite the blood shedding of our fellow countrymen in the Civil War) is the following: whether Spain is a nation in the liberal sense, i. e. a sovereign community, with a representative political system and a form of governmental autonomy, sustained by the will of its members, which are protected by a common law that concerns them, even if they were not directly responsible for its formulation; or whether, on the contrary, it is rather a nationality in the old Greek sense, almost similar to a City (polis): a living organism, a process, grown and dead within the slow historical formation of a people linked to a territory, with a common language and traditions, with shared customs.

Keywords: Nation, nationality, land, Constitution, liberalism, organicism. 
“¡Yo soy españó!

Yo soy de la tierra dichosa

del vino y del sol.

¡Yo soy españó!

¡Me carga la Constitución!”.

Coplas de Españita, de: La patria chica (1907). Zarzuela de Ruperto Chapí, con libreto de Serafín y Joaquín Álvarez Quintero.

“'Soy español!

Y los millones de hombres que murieron por España y por la fe de Jesucristo, y los que hicieron las catedrales y los castillos, y los que descubrieron América son mis abuelos".

Agustín Serrano de Haro, Yo soy español, Madrid, Escuela Española, 1951.

\section{Introducción: en busca del ser de España}

A pesar de las contundentes afirmaciones del exergo, creo que, desde hace mucho tiempo ( si es que no ya desde el comienzo ${ }^{1}$ ), algo raro debe de haber en este país denominado "España" para que un filósofo tan comedido, razonable y, sobre todo, agnóstico como era Don José Ortega y Gasset se creyera obligado a apelar nada menos que a Dios para preguntarle por el ser esencial de España: "Dios mío, ¿qué es Es-

\footnotetext{
${ }^{1}$ En su De antiqua Judaeorum origine (I, 6, 1), señala Flavio Josefo: "fundó Tubal (Thobel) a los tubelos, a los que ahora se llaman iberos". Ahora bien, había dos pueblos iberos, uno en el Cáucaso (la actual Georgia) y otro en Europa (la actual Península Ibérica), con lo cual, de un lado, ni siquiera cabe estar seguro de si esa mítica fundación se refiere a España; pero del otro, esa extrema dualidad geográfica dio pábulo a la idea de la estrecha semejanza (también lingüística, según Wilhelm von Humboldt) entre el supuesto pueblo primitivo de Iberia: los vascos, y los antiguos habitantes del Cáucaso, algo sostenido aún por algunos euskal herritarak amantes de lo ancestral para -introduciendo aún mayor confusión- hacer depender su origen, no de Tubal, sino de Aitor, hijo de Tubal-Caín (herrero de la raza de Caín, según Genesis 4, 22; cf. De antiqua... I, 2, 2), con lo cual los vascos tendrían un origen antediluviano, mientras que los españoles habrían de conformarse con que Tubal fuera tan sólo hijo de Jafet y nieto de Noé (Genesis 10, 3). Ulteriormente, en su exégesis de un pasaje de Ezequiel (38,2-3), San Jerónimo dudará todavía de si: “Thubal autem sive Thobel aut Italia interpretatur aut Iberia, hoc est Hispania, ab Ibero flumine, unde et hodie Hispaniarum regio appellatur Celtiberia". Pero San Isidoro -no sin displicente condescendencia para con los italianos- zanjará pro domo (nunca mejor dicho) la cuestión, estableciendo el dogma del tubalismo español para toda la Edad Media: "Thubal, a quo Iberi, qui et Hispani; licet quidam ex eo et Italos suspicentur" (Etymologiarum sive Originum liber IX, 29). Cf. Juan Aranzadi, Milenarismo vasco. Edad de oro, etnia y nativismo, Madrid, Taurus $2000^{2}$, y J. A. Estévez Sola, Aproximación a los orígenes míticos de Hispania, HABIS 21, 1990, pp. 139-152.
} 
paña?"2. No estaba solo en ese su desasosiego. Al menos desde San Isidoro de Sevi$11 a^{3}$ hasta la aparición en este mes de junio de 2013 de un voluminoso conjunto de estudios denominado: Ser españoles. Imaginarios nacionalistas en el siglo $X X^{4}$, se han sucedido sin apenas interrupción toda suerte de alabanzas y lamentaciones ${ }^{5}$, de ditirambos $^{6}$, denuestos ${ }^{7}$ y hasta de descalificaciones sumarias ${ }^{8}$ relativas a este país.

\footnotetext{
${ }^{2}$ Meditaciones del Quijote (1914). Obras Completas (= O.C.), Madrid, Revista de Occidente, 1963-1969, I, p. 360).
}

3 "Tú eres, oh España, sagrada y madre siempre feliz de príncipes y de pueblos, la más hermosa de todas las tierras que se extienden desde el Occidente hasta la India. Tú, por derecho, eres ahora la reina de todas las provincias, de quien reciben prestadas sus luces no sólo el ocaso, sino también el Oriente". Las historias de los Godos, Vándalos y Suevos (Ed. de Cristóbal Rodríguez Alonso), León, Centro de Estudios San Isidoro, 1975, p. 169.

${ }^{4}$ Se trata de un conjunto de 16 estudios y una Introducción, editado por Javier Moreno Luzón y Xosé M. Núñez Seixas, Madrid, RBA, 2013 (citaremos directamente en el texto como: Ser españoles).

${ }^{5}$ Baste citar al respecto el terrible poemario de César Vallejo, escrito en 1937, en las angustias de la Guerra Civil, y en cuyo último poema se invierte la imagen de la mater genitrix isidoriana: "si la madre España cae -digo, es un decir- / salid, niños del mundo; id a buscarla!" España aparta de mí este cáliz (1 $1^{\text {a }}$ ed. 1939), Madrid, Árdora Ediciones, 2013. Por cierto, he aquí un posible sentido de esa "inexistencia" de España-Nación, que incita a una cumplimentación futura, a partir de la diáspora y del retorno plural, no de la centralidad identitaria.

${ }^{6}$ Sobresaliendo de entre el prevaleciente nacionalismo banal de hoy, brilla Eviva España, un pasodoble flamenco (en los dos sentidos: por lengua y por tema) de 1972, con música de Leo Caerts y letra de Leo Rozenstraten, y cuya versión española ha acabado por convertirse en un quasi himno nacional. Ésta es la estrofa inicial (en la que, una vez más, aparece España como madre): "Entre flores, fandanguillos y alegrías, / nació en España la tierra del amor / Sólo Dios pudiera hacer tanta belleza, / y es imposible que puedan (sic!) haber dos".

${ }^{7}$ Un buen ejemplo es el de la poetisa gallega Rosalía de Castro (que identifica Castilla con España, como ahora se hace con "Madrid"): "Permita Deus, casteláns, / casteláns que aborrezo, /que antes os galegos morran / que ir a pedirvos sustento. [...] / ¡Casteláns de Castela, / tendes corazón de aceiro, / alma coma as penas dura,/ e sen entrañas o peito!" ("Castellanos de Castilla”, en: Cantares gallegos [1863], Madrid, Cátedra, 2005).

${ }^{8}$ Aunque luego dedicara una vida entera a matizar su diagnóstico de los males de la patria, el mismo Ortega que apostrofaba a Dios y le inquiría sobre el ser de España había ya despachado despectivamente la pregunta ocho años antes, en La conservación de la cultura: "España no es nada; es una antigua raza berberisca, donde hubo algunas mujeres hermosas, algunos hombres bravos y algunos pintores de retina genial. Mas por su alma no han pasado ni Platón, ni Newton, ni Kant, y con una terquedad incomprensible viene cometiendo, desde hace tres siglos, el gran pecado contra el Espíritu Santo: la incultura, el horror a las ideas y a las teorías" (O. C.; X, 44). En nuestros días, Enrique Lynch ha contextualizado la pregunta "¿Por qué está mal la universidad española?", remitiéndola al carácter fallido de ese "ser" tan buscado: "España es un país desvertebrado nacido de una guerra secular de reconquista en la que los bárbaros se impusieron sobre la nación árabe civilizada y que, acto seguido, expulsó a sus judíos y emprendió la conquista y el expolio de las Indias occidentales [...] y acabó [...] sumiéndose en una guerra civil fratricida que desembocó en una dictadura fascista". Y así, esta rotunda y extremosa actualización de la tesis 
Sea como fuere, se supone que lo menos que puede ser España es ser una nación. Y así se reconoce, en efecto, en el título mismo de este ensayo (y no sólo en él, claro); sólo que este predicado, tan sustancial, viene relativizado (como corresponde a un sustantivo calificado o matizado por una oración de relativo) al negar que esa determinación pueda convenir al del sujeto. Más que ante una contradicción, estamos aquí ante una paradoja: lo afirmado como propio de un país determinado viene denegado en cuanto a su existencia como tal. Y ello, por dos motivos: primero, porque uno abriga la sospecha de que el sujeto "España" (de cuya existencia -si no metafísica, sí al menos como "persona" jurídico-política- no cabe dudar") se niega o manifiesta una franca reticencia a ser calificada como nación; y en segundo lugar, porque quizás el término "nación" no tenga un significado bien perfilado, de modo que mal puede servir esa blurry notion para localizar y definir como "naciones" las entidades políticas reconocidas en los foros internacionales ${ }^{10}$. Lo llamativo del caso es que esta mi doble dubitación, una vez contrastada, parece corresponder a una igualmente doble incertidumbre respecto a la cosa misma. Para empezar, y como se acaba de indicar, porque ni siquiera está claro qué sea en general una "nación". Y para seguir, porque, de atender a la "Carta" que un país se manda o destina a sí mismo (o más bien a sus ciudadanos, presentes y futuros) para reconocerse y ser reconocido como un Estado de Derecho, o sea: de fijarse en la Constitución, no está claro que España sea o haya sido una "nación". O peor: que lo haya querido ser o incluso que lo quiera ser ahora. Y después, porque ni siquiera está claro qué sea en general una "nación". Ahora bien, es posible que el examen de esa desazonadora indecisión arroje alguna luz sobre tan esquivo tema, más allá de las declamaciones y reclamaciones emocionales sobre la "esencia" española, recientemente evocadas. Pues adviértase que no se dice: "España no es una nación", sino: "España es la nación que no existe", o sea: esta nación determinada (resuelta, destinada) a no ser tal cosa.

\footnotetext{
de Américo Castro contra Sánchez Albornoz, acaba coincidiendo enteramente con la sentencia condenatoria de Ortega: “¿cabía esperar que esa sociedad produjera una cultura técnica, científica o humanística relevante o una comunidad instruida en los valores del saber y las artes? Por supuesto que no" (Julio, 2010. www.letraslibres.com $>$ Revista $>$ Convivio).

${ }^{9}$ Recuérdese que Ortega pregunta: “¿qué es España?”, no si “existe España”.

${ }^{10}$ Un simple rastreo por el buscador google de Internet pone de manifiesto que la pregunta: “¿Cuántas naciones hay en el mundo?" no tiene respuesta, o bien se cambia automáticamente la cuestión por: “Cuántos países hay en el mundo?” (Combien de pays dans le monde?, How many countries in the world?, Wie viele Länder gibt es weltweit?). En español, la página web Naciones del mundo está dedicada -como cabía sospechar- a recoger opiniones sobre las llamadas "naciones irredentas" (sobre todo en España, y contra España). Un cálculo imposible de verificar afirma que hay 69 comunidades de este tipo que aspiran violenta o pacíficamente a convertirse en Estados independientes, cumpliendo así la vieja y concisa definición de Bartolo de Sassoferrato: Civitas sibi princeps est.
} 


\section{Buscando una noción para la Nación}

¿Qué es una nación? A pesar de la notable conferencia pronunciada por Ernest Renan con ese título ${ }^{11}$ en la Sorbona el 11 de marzo de 1882, y del impacto expansivo que ha tenido desde entonces (y sigue teniendo: el texto figura en el programa de examen de la función pública francesa), el celebérrimo escrito está a mi ver lastrado por algunos presupuestos que lo hacen difícilmente viable como propuesta de solución de los problemas actuales sobre el sentido del término "nación" (y de su inquietante derivado: el "nacionalismo irredento"), por lo que a España concierne. Para empezar, Renan piensa a partir de una coyuntura histórica en la que Francia debía consolidar las esencias liberales, tras la débacle del Segundo Imperio en la Guerra Franco-Prusiana, con la pérdida de Alsacia y de Lorena, por un lado, y el malogrado intento de la Commune, por otro. En una suerte de contrafigura de las Reden an die Deutsche Nation, de Fichte (1807), la intención de Renan es hallar (o más bien, "inventar", en el sentido propuesto por Kant de una historia escrita a priori ${ }^{12}$ ) una conciencia nacional francesa que no esté basada en los elementos constituyentes de la Kultur, sensu germanico (la lengua, la religión, la geografía, la tierra natal, y sobre todo la $\mathrm{raza})^{13}$. Pues el problema estaría en cómo pasar entonces de la sangre o la tierra (factores de desigualdad) a la conciencia misma de nación, en cuanto factor identitario. Por decirlo con Goethe: en este caso faltaría justamente el vínculo espiritual. Esta devaluación de los elementos "tradicionales" apunta a un intento de contrarrestar la pujanza de lo autóctono, de acuerdo con la etimología de natio (de nascor, "nacer": la tierra en que se nace y muere), como se muestra en los ejemplos aducidos por Renan: los Estados-Nación constituidos tras el Congreso de Viena y sus secuelas. Por otro lado, es interesante añadir que Renan tampoco contempla como factor esencial de unión la comunidad de intereses, es decir la economía ${ }^{14}$. Por cierto, esta

\footnotetext{
${ }^{11}$ Se cita por la ed. bilingüe de F. Ochoa de Michelena: Ernest Renan, ¿Qué es una nación?, Madrid Sequitur, 2001, p. 83. Cf. también: Qu'est-ce qu'une nation? Suivi de Le judaïsme comme race et comme réligion (Éd. de Shlomo Sand), Paris, Flammarion, 2011.

${ }^{12}$ Cf. I. Kant, Der Streit der Fakultäten. 2. Absch. 2. En: Werke. Akademie Textausgabe, Berlin, 1968; VII, 80.

13 "La conscience instinctive qui a présidé à la confection de la carte d'Europe n'a tenu aucun compte de la race, et les premières nations de l'Europe sont des nations de sang essentiellement mélangé" (op.cit., p. 63).

14 "La communauté des intérêts est assurément un lien puissant entre les hommes. Les intérêts, cependant, suffisent-ils à faire une nation ? Je ne le crois pas. La communauté des intérêts fait les traités de commerce. Il y a dans la nationalité un côté de sentiment ; elle est âme et corps tout à la fois ; un Zollverein n'est pas une patrie" (op.cit., p. 63). Por cierto, una obra mucho más extensa, y tan famosa en su tiempo como el escrito de Renan en el suyo, se arrima en cambio con total franqueza al crecimiento económico como fuente de bienestar y elemento civilizador de las naciones: "C'est là enfin que, voyant à mes pieds, ces belles contrées où fleurissent les sciences \& les arts, \& que
} 
referencia crítica podría aplicarse hoy al way of life anglosajón, extendido hoy como World Business Culture ${ }^{15}$.

Nihil novi sub sole. Sea de ello consciente o no, Renan está participando así en una secular polémica: la habida -también con siglos de distancia- entre Cicerón y San Agustín, y que no dejará de ser relevante para nuestro examen. En efecto, Cicerón (por boca de Escipión el Africano) defendía explícitamente que para la formación de la res publica era necesaria justamente la mencionada "comunidad de intereses", junto con el consenso jurídico (o en los conocidos términos ingleses: the rule of law) ${ }^{16}$. San Agustín, en cambio, que glosa por extenso la doctrina de Cicerón, objeta a éste que la sola iustitia y el solo interés no bastan para formar un pueblo, proponiendo en cambio, en estrecha correlación con su concepción del ordo amoris y del alma como cohesión y tensión a la vez, una definición de "pueblo" como: coetus multitudinis rationalis, rerum quae diligit concordi communione sociatus ${ }^{17}$. Renan, ça va sans dire, está más cerca de esta posición "atractiva" (mediadora, si se quiere, entre lo germánico y lo anglosajón), pero imprimiéndole un giro, diríamos, autorreferencial. Mientras que en San Agustín el pueblo se constituye en civitas mediante la "concorde comunión de las cosas que ama", o sea de algo externo al pueblo mismo (sea el goce de los bienes en paz -la tranquillitas animi-, sea la entrega perfecta a Dios), en Renan pesa decisivamente la idea rousseauniana de volonté générale a la que deben some-

les ténèbres de la barbarie avoient si longtemps occupées, je me suis demandé : qui est-ce qui a creusé ces canaux ? Qui est-ce qui a desséché ces plaines? Qui est-ce qui a fondé ces villes ? Qui est-ce qui a rassemblé, vêtu, civilisé ces peuples? \& qu'alors toutes les voix des hommes éclairés qui sont parmi elles m'ont répondu : c'est le commerce, c'est le commerce". Guillaume-Thomas [Abbé] Raynal, Histoire philosophique des Deux-Indes. Introduction générale (1770), Genève, Pallet, 1780; Livre I., p. 3.

${ }^{15}$ En la página web: World Business Country puede compararse el ranking de las naciones. Lejos está la idea, de raigambre lebniziano-herderiana del gran "concierto de la humanidad" como fin de la historia: "Par leurs facultés diverses, souvent opposées les nations servent à l'œuvre commune de la civilisation ; toutes apportent une note à ce grand concert de l'humanité, qui, en somme, est la plus haute réalité idéale que nous atteignions" (Renan, op. cit., p. 93). Por cierto, el Concert des Nations es ahora ya, solamente, el nombre de una orquesta especializada en música barroca.

${ }^{16}$ Est igitur [...] res publica res populi, populus autem non omnis hominum coetus quoquo modo congregatus, sed coetus multitudinis iuris consensu et utilitatis communione sociatus. eius autem prima causa coeundi est non tam inbecillitas quam naturalis quaedam hominum quasi congregatio. ("Es pues [...] la república [lit.: la cosa pública] cosa del pueblo; sólo que pueblo no es todo conjunto de hombres reunido de cualquier manera, sino el conjunto de una multitud asociada por un mismo derecho y por la comunión de intereses. La causa originaria de esa conjunción no es tanto la indigencia humana cuanto cierta tendencia asociativa natural de los hombres."). Cicerón, De re publica I. 25, 42); Epítome en S. Agustín, De civitate Dei, II. 21).

${ }^{17}$ Populus est coetus multitudinis rationalis, rerum quae diligit concordi communione sociatus. ("Pueblo es el conjunto de una multitud racional, vinculado por concorde comunión de las cosas que ama”. San Agustín, De Civitate Dei, XIX. 24). 
terse, y en la que deben integrarse, todos los individuos (pues lo que éstos aman sobre todo, si constituyen una nación, no es la divinidad ni la tierra ni los bienes, sino algo previo a todo ello: aman el hecho de constituirse en un Nosotros; aman la convivencia, la persistencia histórica, el empeño en seguir juntos).

Sólo que esa volonté debería venir espiritualizada y personalizada en algo que bien podríamos denominar el Volksgeist, en el sentido preciso conferido por Hegel al término, a saber: el "contenido determinado, el cual recibe la forma de la universalidad $^{18}$ y se halla dentro de la efectiva realidad concreta que es el Estado"19. Deberíamos guardarnos de ver en esta "entidad" algo metafísico; y menos aún, mítico. Por un lado, del Volksgeist dice Hegel a continuación que "el estado realmente efectivo está vivificado (beseelt) por este espíritu". Y sabemos que el "alma" (Seele) es sólo el íncipit del espíritu, en cuanto: "universal inmaterialidad de la naturaleza, su simple vida ideal (ideell) ${ }^{20}$. Por eso, es el individuo libre y consciente de sí el que, en la esfera política, ha de llevar a perfecta cumplimentación la conjunción dialéctica de la forma (la universalidad estatal) y el contenido (la particularidad de la nación): "Pero el hombre tiene que saber también de ese su espíritu y esencia, y darse la conciencia de la unidad con la misma. Pues [...] lo ético (das Sittliche) es la unidad de la voluntad subjetiva y la universal" (ib.).

Se anuncia aquí, implícitamente, un punto a mi ver fundamental para una mejor inteligencia del concepto "nación"; un punto al que, sin embargo, no estoy seguro de que Renan (y Ortega, tras sus huellas) haya prestado la atención suficiente como para salir de un impasse de tipo subjetivista y voluntarista; pues, precisamente para huir del pantanoso magma germánico del suelo y la sangre, del roquedo y del roble, él procede, creo, como si la Nation fuera una fusión de voluntades individuales para formar un alma, identificada al punto con "un principio espiritual" 21 , un principio "resultante de las complicaciones profundas de la historia, una familia espiritual, no un grupo determinado por la configuración del suelo" (ib.). Sólo que esa historia se mantiene porque los individuos deciden tener muchas cosas en común y a la vez olvidar muchas cosas. ¿Para qué? Para seguir juntos, haciendo y deshaciendo, proyectando y olvidando. Estamos al borde de la tautología.

\footnotetext{
${ }^{18}$ Esa forma es la Bildung einer Nation, la cual "se manifiesta en el Estado y viene a ser consciente de sí", como se dice en la frase anterior al texto citado.

${ }^{19}$ G. W. F. Hegel, Vorlesungen über die Philosophie der Weltgeschichte.- Einleitung. C.c). En: Werke, Frankfurt/M., Suhrkamp, 1970; 12, 69.

${ }^{20}$ G. W. F. Hegel, Enzyklopädie [1830] § 389 (Anthropologie). El parágrafo concluye acentuando el carácter sustancial, pasivo de este espíritu incipiente: "Pero en esta determinación, todavía abstracta, el alma es sólo sueño (Schlaf) del espíritu”. Werke 10, 43.

21 "Une nation est une âme, un principe spirituel." E inmediatamente antes había escrito: "L'homme est tout dans la formation de cette chose sacrée qu'on appelle un peuple" (Renan, op. cit., p. 83).
} 
Adviértase que, de este modo, ni siquiera cabría hablar de una historia compartida como una línea continua en el tiempo, sino más bien de una suerte de creacionismo político: la Nación se mantiene en el tiempo a cada instante porque así lo quieren sus ciudadanos, al igual que el mundo se crea a cada instante porque el buen Dios cartesiano así lo quiere. Conocemos la metáfora (según el propio Renan): "la existencia de la nación es un plebiscito cotidiano." Y por si no cupieran dudas de esta depuración de todo lo natural (de todo lo "nacional", cabría decir), añade: "al igual que la existencia del individuo es una afirmación perpetua de vida" ${ }^{22}$. Perpetua, añadiría yo, mientras el cuerpo aguante (o sea, mientras aguanten los componentes de una nación siempre en trance de dejar de ser y de llegar a ser). De este modo, los "viejos organismos" que son las naciones estarán sometidos al albur de los individuos componentes, o sea a "voluntades a menudo poco ilustradas", hasta llegar a la "secesión" y el "desmenuzamiento de las naciones" 23 . Es curioso: Renan se vanagloria, y con razón, de haber dado de lado con su propuesta todas las abstracciones metafísicas y teológicas. Pero sigue contando con la más obstinada de las abstracciones: la del hombre. Eliminadas aquellas abstracciones, el propio autor se pregunta qué es lo que resta, entonces. Podemos adivinar su respuesta: Il reste l'homme, ses désirs, ses besoins (ib.). Puro decisionismo abstracto. Nationem et individuum scire cupio. Nihilne plus? Nihil omnino ${ }^{24}$.

\footnotetext{
22 "L'existence d'une nation est (pardonnez-moi cette métaphore) un plébiscite de tous les jours, comme l'existence de l'individu est une affirmation perpétuelle de vie" (ibidem).

23 "La sécession, me direz-vous, et, à la longue, l'émiettement des nations, sont la conséquence d'un système qui met ces vieux organismes à la merci de volontés souvent peu éclairées. Il est clair qu'en pareille matière aucun principe ne doit être poussé à l'excès. Les vérités de cet ordre ne sont applicables que dans leur ensemble et d'une façon très générale. Les volontés humaines changent ; mais qu'est-ce qui ne change pas ici-bas ? Les nations ne sont pas quelque chose d'éternel. Elles ont commencé, elles uniront. La confédération européenne, probablement, les remplacera" (Renan, op. cit., p. 91). Esta última solución "kantiana" le deja a uno perplejo: si ya aunar voluntades torpes suele ser complicado, y la mutua discordia puede llevar a la disolución de una nación, ¿cómo atajar el mal mediante una mucho más grande "confederación europea"? Si unos pocos individuos son incapaces de permanecer agrupados, ¿cómo lo van a lograr de forma mejor y más duradera juntándose a muchos más individuos, cada uno de su (ex)nación? No parece sino que los problemas de la actual Unión europea estaban ya implícitamente cerniéndose, ominosos, sobre las democráticas intenciones de Ernest Renan.

${ }^{24}$ Renan no está solo en esta concepción de un Leviathan al revés, singular y espiritual, siempre a pique de dejar de ser, pendiente de que los individuos que lo componen decidan no irse al extranjero. Trece años antes de la famosa conferencia, Jules Michelet iniciaba su monumental Histoire de France recordando cómo ésta se había ido gestando al calor de la Revolución de Julio de 1830, y cómo ese acontecimiento histórico le había hecho dudar del valor efectivo de los sabios empeñados en penetrar en el sentido genuino de Francia. Y así, exclama con orgullo: "Nul ne l'avait encore embrassée du regard dans l'unité vivante des éléments naturels et géographiques qui l'ont constituée. Le premier je la vis comme une âme et une personne". Préface de 1869. En: Euvres Complètes. Histoire de France. Moyen Âge, Paris, E. Flammarion, 1893, I, 1.
} 
¿Qué se oculta tras tantas ganas de convivencia, y tras tan voluntarioso "plebiscito cotidiano"? Pues, para este caso, parece que más valdría el viejo "contrato social", signado una sola vez in illo tempore por los ciudadanos (libres o medrosos, según queramos escoger a Locke o a Hobbes). Lo que se oculta, creo yo, es la licuefacción liberal del hecho tremendo de la Revolución Francesa, y el deseo de renovarla, moderada, en la Tercera República. Era la revolución de 1789 la que había abstraído de toda diferencia que tuviera que ver con la tierra natal (empezando por la unificación del idioma francés y del sistema de pesos y medidas: factores de unificación que Renan pasa por alto), dejando tan sólo un territorio cuadriculado, unos ciudadanos sujetos a leyes iguales... y entregados a la desigualdad radical del capitalismo industrial y financiero. Sólo que esta maquinaria social se nutre justamente del aprovechamiento y usura de los recursos pertenecientes a la nación. De modo que, cuando al cabo de la calle (ahora, neoliberal), no solamente los recursos ecológicos sean esquilmados al extremo, sino que también grupos humanos incapaces de seguir arraigados en los territorios que han sufrido la devastación capitalista se vean obligados a emigrar en masa a países que, en buena medida, son precisamente responsables de la destrucción del entorno en que esos grupos vivían, ¿qué respuesta cabe esperar, sino la de una reactivación virulenta y esencialista de la propia etnia, convertida imaginaria y voluntariosamente en una nación propia?

Ello ha originado un trastorno en la valoración axiológica, difícil de comprender para tantos demócratas y liberales que, intentando hacerse una idea de lo que pueda ser una nación, han seguido la estela de Renan ${ }^{25}$. En efecto, desde la óptica decimo-

\footnotetext{
${ }^{25} \mathrm{Y}$ entre los que cabe contar desde luego con Ortega y Gasset, cuyo decisionismo raciovitalista se alía con una peligrosa exaltación de las minorías rectoras, guiadas a su vez por una aristocracia del espíritu: una especie de Corporación del "universal" hegeliano, ahora en sentido cosmopolita... sólo para los intelectuales egregios que se reconocen entre ellos a través de las naciones y los tiempos. Y es que Ortega cree advertir a dónde ha llevado el individualismo voluntarista de Renan: no tanto al socialismo, sino al hombre-masa de la clase media. La crítica al liberalismo era seguramente correcta: como se ha señalado, faltaba justamente un término medio, constitutivo de lo "nacional" (un terminus medius que en Renan parece aludir más bien a un vago "republicanismo parlamentario", de corte liberal). En este sentido, la ironía orteguiana no deja de tener gracia: al referirse a la inquietante situación política en España durante el siglo XIX, dice que, por entonces: "cada hombre o grupo humano quiso mandar sobre los demás, y cuando esto era imposible, inventó la manera de que, al menos, no mandase nadie, con la secreta esperanza de que, hallándose vacante el Poder, pudiese en una hora de descuido arrebatarlo cualquiera."Pleamar filosófica. LA NACION, de Buenos Aires, 10 de mayo de 1925 (O.C.; III, 345). Sólo que, si algo de razón hay en la crítica de ese achatamiento ("Allanad las montañas, y el mar os estará agradecido", reza el aforismo 12 de Glauben und Liebe, de Novalis), las razones aducidas por Ortega sobre su génesis no pueden ser más aberrantes, por decirlo suavemente. Ese achatamiento se habría producido por la progresiva falta de hombres egregios (de guías, pues, de la grey o rebaño: pastores laicos, por así decir), como habrían sido, por caso, los señores feudales en el Medievo (por cierto, una de las
} 
nónica (vigente al menos hasta 1950), la confrontación entre progresistas y conservadores pasaba por el uso del disputado término "nación". Ahora bien, esa utilización venía aplicada en exclusiva (prácticamente hasta las dos grandes revoluciones del s. XVIII, la americana y la francesa) para designar a los notables del reino: el estamento aristocrático y el eclesiástico (justamente eso que Ortega echaba en falta en su tiempo: las minorías rectoras), dejando aparte a los llamados communes. Todavía Montesquieu, hablando de las dos "estirpes" (races) que se encontraban en la Francia incipiente de la Alta Edad Media: los burgundios al Oeste y los visigodos de la Galia Meridional, identifica nation con lo que un alemán llamaría más bien Thing o Versammlung, o sea: "asamblea de notables"26.

Por lo demás, esta idea "aristocrática" de nación como asamblea para tratar asuntos de gobierno implicaba desde luego la necesidad de utilizar un lenguaje común; de modo que, cuando los Estados surgidos de la descomposición del Imperio Romano de Occidente necesiten un factor de aglutinación -aparte del latín como lingua franca de las cancillerías-, la lengua vernácula será un factor decisivo de unificación (digamos, contra Renan y a favor de la tesis de Fichte).

razones de la decadencia de España habría sido la falta en ella de feudalismo, según Ortega). Así que el "hombre-masa" -piensa Ortega- exigirá a un Estado tan anónimo como él que todo se lo dé hecho y que arregle cualquier problema que pudiera molestarlo en su modorra: "el hombre-masa ve en el Estado un poder anónimo y como él se siente a sí mismo anónimo -vulgo-, cree que el Estado es cosa suya. Imagínese que sobreviene en la vida pública de un país cualquier dificultad, conflicto o problema; el hombre-masa tenderá a exigir que inmediatamente lo asuma el Estado, que se encargue directamente de resolverlo con sus gigantescos e incontrastables medios." (La rebelión de las masas [1930]. O.C.; IV, 225). Y el problema es que el filósofo no encuentra hoy por lado alguno esas minorías rectoras, que serían en última instancia las forjadoras de la nación. Pues, y ésta es la propuesta orteguiana para definir nuestro término: "Una nación es una masa humana organizada, estructurada por una minoría de individuos selectos." (España invertebrada. O.C.; III, 93; poco antes había repetido la metáfora de Renan: "una nación es un plebiscito cotidiano." III, 71). En el breve espacio de una nota, cabría matizar al respecto que -al menos en España y en la época de Ortega- no eran desde luego las masas, sino normalmente el "señorito", el terrateniente o el empresario (por no hablar del Ejército) quien creía que la "estructura" de la nación (o sea, el Estado) era "cosa suya", y quien exigía que las "fuerzas" y los "poderes" del Estado le resolvieran los problemas particulares -sobre todo cuando eran de "orden público"-, mientras que el campesino, el jornalero o el obrero veía con impotencia cómo se conculcaban sus derechos más elementales.

26 "Sous les deux premières races, on assembla souvent la nation, c'est-à-dire les seigneurs et les évêques: il n'était point encore question des communes" (De l'esprit des lois. L. XXVIII, ch. IX. En: Oeuvres complètes (Ed. de Daniel Oster), Paris, Seuil, 1964. Coll. l'Intégrale). Pocos años después, serán justamente esos "comunes" los que reivindicarían para sí el título de "nación". El título mismo del ensayo del Abbé Sieyès: Qu'est-ce que le tiers état? (1789) anticipa la generalización de lo preguntado en Renan, en 1882. 
Un interesante ejemplo de la estrecha conexión entre "nación", como conjunto de representantes de los altos estamentos del Estado (una idea que, "intelectualizada", brilla todavía con fuerza en la definición orteguiana de nación, citada en nota 25), y la necesidad de utilizar un idioma exclusivo para los asuntos de gobierno, se encuentra en la propuesta de Elio Antonio de Nebrija de complementar el encargo que le hiciera Isabel la Católica de elaborar una edición bilingüe de sus Introductiones latinae (1481), ofreciendo al efecto, como introducción a las Introductiones ${ }^{27}$, el proyecto en el que él -con verdadera visión de Estado- estaba realmente interesado: una Gramática sobre la lengua castellana (por cierto, la primera que se hiciera de una lengua vulgar, en el mismo año de la rendición de Granada y del descubrimiento de América). La justificación de Nebrija para redactar una obra que no le había sido encargada (más bien parece que la Reina no estaba interesada en la propuesta) es realmente sutil y envolvente: confiesa que su "pensamiento e gana siempre fue engrandecer las cosas de esta nacion e dar a los hombres de mi lengua obras en que mejor puedan emplear su ocio: que agora lo gastan leyendo novelas o istorias envueltas en mil mentiras e errores", para identificar luego la nación y su engrandecimiento con "la memoria de vuestros loables hechos", a fin de que "vuestros cronistas e istoriadores" empleen en efecto mejor su ocio describiendo las gestas de la NaciónMonarquía, en vez de "passar en castellano las cosas peregrinas e estrañas, pues que aqueste no puede ser sino negocio de pocos años" 28 . No es necesario hacer ver la cercanía de estas críticas a las expuestas ciento cincuenta años después al inicio del Discours de la méthode. Sólo que Descartes se aprestará a echar los fundamentos de una mathesis universalis, mientras que Nebrija, más modesto, sólo pretende que, con ayuda de la Gramática, los historiadores y cronistas "encomienden a inmortalidad" las gestas de la incipiente Nación Española; o dicho de otro modo: que pongan los $\mathrm{ci}$ mientos de la identidad española (por cierto, a través de Castilla y su lengua ${ }^{29}$ ), in-

\footnotetext{
${ }^{27}$ Como se aprecia en el Prólogo de la Gramática, alguno de cuyos puntos comentaré, Nebrija "justifica" su propia obra ante la Reina, haciendo ver que de este modo los eruditos españoles podrán aprender más fácilmente el latín y hacerlo más refinado y pulido. Y desde luego, la edición bilingüe de las Introductiones apareció antes que la Gramática misma: ésta no era para Isabel sino un mero medio auxiliar de aproximación a la lengua culta.

${ }^{28}$ A. de Nebrija, Gramática sobre la lengua castellana (Salamanca 1492) (Ed. C. Lozano), Madrid, Academia Española / Galaxia Gutenberg / Círculo de Lectores, 2011, p. 6.

${ }^{29}$ El Prólogo está dedicado a Isabel: "señora natural de españa e las islas de nuestro mar." Naturalmente, Nebrija no podía saber que en ese mismo año se descubriría América. Dicho sea de paso: actualmente existe una universidad privada en Madrid denominada "Antonio de Nebrija", en la que se ofrece una Business School además de un "contrato" llamado Nebrija Valley, por el que se pone en contacto a los estudiantes (en cuanto futuros profesionales) con empresas como Tuenti, Bridgestone o Microsoft. He aquí un modo actualizado de: "engrandecer las cosas de esta nación", en nombre del gran humanista.
} 
mutable a través de los siglos gracias a la escritura. En efecto, igual "que se a hecho en la lengua griega e latina", los hechos relevantes del incipiente Imperio podrán "entenderse en toda la duracion de los tiempos que está por venir" ( $i b$.). He aquí un modelo soberano de cómo se empieza a construir ese "artefacto cultural" de larga duración que Benedict Anderson ha denominado imagined community ${ }^{30}$.

Con todo, y como ya se ha insinuado antes, el verdadero problema no estará tanto en el paso de la aplicación del sustantivo "nación" de la Edad Media a la Edad Moderna, cuanto en su aplicabilidad a los individuos que la componen y que, por ello, abrigan un sentimiento de pertenencia a una nacionalidad. Y ello quiere decir: cuando la disolución de los antiguos estamentos de la Nación dejen paso a representantes que ya no pueden limitarse a ser representación de su propia casta y delegación de la Realeza, sino que han de serlo igualmente del pueblo representado, y representado ya no en la escritura y registro de las hazañas de los claros varones de España $a^{31}$, sino en una Constitución, en la que el Pueblo se da a sí mismo existencia (al principio, eso sí, por parte del Monarca y bajo la mirada de Dios) $)^{32}$.

Curiosamente, la más sonada polémica del siglo XIX sobre el sentido y función de la nacionalidad se dará sin embargo en un país como Inglaterra, sin más "constitución" que la Magna Charta Libertatum (1215); una nación que, después de la llamada Glorious Revolution (1688) y la pérdida de las colonias americanas, está decidida a impedir en su suelo toda aventura "nacionalista". La cuestión aquí en juego es, obviamente, la de la conexión entre la nacionalidad y el Estado, entendido ya como un gobierno representativo. Y no es extraño que sea un liberal como John Stuart Mill el que haga descansar en 1861 la base de la nación en un feeling compartido por un mismo grupo de

\footnotetext{
${ }^{30}$ Benedict Anderson, Imagined Communities. Reflections on the Origin and Spread of Nationalism, London/New York, Verso, $2003^{13}$.

${ }^{31}$ Hernando del Pulgar, cronista de los Reyes Católicos, escribe en 1486 Claros varones de Castilla. Años después, la obra se convierte en: Los claros varones de España: hecho por Hernando del Pulgar. Dirigidos a la muy alta Reyna Doña Ysabel Reyna de Castilla, Sevilla, Stanislao Polono, 1500 (hay ed. actual en: Barcelona, Salvat, 1970). Repárese en la interesada expansión de Castilla como "España".

${ }^{32}$ El Preámbulo de la Déclaration des Droits de l'homme et du citoyen du 26 août 1789 concluye así : "En conséquence, l'Assemblée Nationale reconnaît et déclare, en présence et sous les auspices de l'Etre suprême, les droits suivants de l'Homme et du Citoyen" (subr. mío). La Constitución del 3 de septiembre de 1791 reproduce literalmente el Preámbulo, salvo esa última frase, ahora suprimida. De todas formas, ya en la Declaration of Independence de los Estados Unidos (1787) ha desaparecido de su Preámbulo toda mención a la divinidad. Las bendiciones son otorgadas ahora por la Libertad: "We the People of the United States, in Order to form a more perfect Union, establish Justice, insure domestic Tranquility, provide for the common defence, promote the general Welfare, and secure the Blessings of Liberty to ourselves and our Posterity, do ordain and establish this Constitution for the United States of America". Por cierto, en esa Constitución no se menciona para nada a la "Nación".
} 
individuos. En efecto, la definición que ofrece Mill de la constitución de una nacionalidad remite simplemente (como después Renan) al deseo de vivir juntos (en función de common sympathies). Subraya así al mismo tiempo la intención expresa de no querer vivir con los demás, como se aprecia en una verdadera cadena de relaciones de inclusión / exclusión: deseo de los ciudadanos de cooperar entre ellos más que con cualquier otro pueblo, de estar "exclusivamente" (exclusively) bajo el mismo gobierno, y de que éste venga en fin formado por la comunidad misma o por una parte de la misma"33. De esa definición se deriva necesariamente una consecuencia de largo alcance, todavía hoy no solucionada (y menos, en el caso de España), a saber: "Es poco menos que imposible que existan instituciones libres en un país formado por nacionalidades diferentes" ${ }^{\prime 4}$. De esto se sigue, a su vez, una tajante disyuntiva: el destino de una nacionalidad sólo puede ser: o bien la separación de las demás o bien su absorción por otra. Tertium non datur. Por cierto, piensa Mill, la absorción le resultaría ventajosa a aquella nacionalidad que: "fuera una porción de la especie humana de origen inferior y más retrasada" 35 . Hay que hacer notar que Mill piensa tan sólo en estados nacionales europeos, ya constituidos, no desde luego en colonias o protectorados (un problema que aquí ni siquiera se plantea). Así, pone como ejemplos al bretón, el vasco y el navarro-francés (integrados en Francia) o al galés y escocés ("miembros de la nación británica"). Por lo demás, si en un país es inviable tanto la separación como la absorción ${ }^{36}$, la única solución que el pensador liberal encuentra parece un mero expediente de compromiso. En ese caso, dice, habría que "hacer de necesidad virtud", e intentar la convivencia en un Estado bajo iguales derechos y leyes, lo cual se aviene mal con lo defendido por Mill, a saber: que el Estado tenga un gobierno representativo.

\footnotetext{
${ }^{33}$ J. S. Mill, 'Of Nationality as Connected with Representative Government', cap. XVI de Considerations on Representative Government. En: Utilitarism. On Liberty. Considerations on Representative Government, London, J. M. Dent \& Sons (Everyman's Library), 1988, p. 391.

34 "Free institutions are next to impossible in a country made up of different nationalities" (op. cit., p. 392).

35 "Experience proves that it is possible for one nationality to merge and be absorbed in another: and when it was originally an inferior and more backward portion of human race the absorption is greatly to its advantage" (op. cit., p. 395).

${ }^{36}$ Mill pone como ejemplo, et pour cause, Hungría (es decir, el "mosaico" que correspondía al Imperio Austro-húngaro), compuesta -señala- de húngaros-magyares, eslovacos, croatas, serbios, germanos y latinos (op. cit., p. 395). Es importante observar que todavía hoy, incluso dentro de la Unión Europea, el problema persiste en la actual Hungría, hasta el punto de que, antes de su ingreso en la Unión (en 2004), la Asamblea Parlamentaria del Consejo de Europa hubo de examinar en 2003 el problema de la Ley de 19 de junio de 2001 de ese país, que definía étnicamente el concepto de "nación", como justificación de la anexión de los enclaves magyares existentes en los países vecinos (Resolution 1335, de 2003: http.//assembly.coe.int). También se da allí el caso inverso: comunidades -como la etnia gitana- dentro del país que no son aceptables por parte de las autoridades... ni de la mayoría magyar.
} 
No parece necesario hacer hincapié en que el problema de las nacionalidades minoritarias se ha agravado vertiginosamente en las últimas décadas, con la inmigración masiva de trabajadores procedentes de las antiguas colonias. Y la solución ofrecida sigue siendo tan pobre y vaga como la de Mill. Así, la Asamblea Parlamentaria del Consejo de Europa, en su Recomendación 1735 (2006), después de reconocer en su punto 3 que, después de dos años de trabajo: "era difícil, por no decir imposible, llegar a una definición común del concepto de "nación""37. De modo que, si era imposible una definición sobre la que asentar las bases de una legislación común europea general, también lo sería a fortiori resolver el problema de las minorías, "incrustadas" o "reivindicadas". El punto 11 de la Recommendation (repárese en que se trata de una mera recomendación, no de una resolución) es tan bienintencionado como inane. La Asamblea "invita a los estados miembros a adoptar acciones legislativas y reguladoras reconociendo a las minorías nacionales tradicionales, y a aplicar aquellas de buena fe (sic!: in good faith)". Y con respecto al problema representativo, que Mill dejaba sin resolver, recomienda: "que los estados apliquen el principio de discriminación positiva a los miembros de las minorías nacionales, especialmente por lo que hace a su representación proporcional en las instituciones centrales y en las descentralizadas (incluyendo cuerpos ejecutivos), en particular en las regiones en que viven esas minorías".

Por cierto, la idea de Mill de la progresiva asimilación de las nacionalidades atrasadas en otras más desarrolladas que, benevolentes, se dignan a acogerlas en su seno, e cosí via, es recogida y remitida ad calendas en el punto 7 de la Recommendation que estamos examinando. Digamos a este respecto que resulta en efecto difícil, ya no aceptar, sino siquiera entender su optimista pronóstico sobre el curso de la historia universal, a saber, la creencia de que: "la tendencia general de la evolución de un Estado-nación va hacia su transformación, según los casos, de un Estado puramente étnico o etnocéntrico a un Estado cívico (a civic state: un Estado de derecho, se supone; F.D.), y de un Estado puramente cívico a un Estado multicultural, en el que se reconocen derechos específicos no sólo a las personas físicas sino también a comunidades culturales o nacionales." A mi ver, dicha "tendencia" parece oscilar más bien entre un pium desiderium y una postergación del problema; y ello, sobre todo por lo que hace al paso de un purely civic state a otro multicultural (como si se dijera: el paso de Francia a Inglaterra o Canadá). Para el caso, más sencillo parecería, orillando los Estados nacionales, proponer -depending on the case- el paso de un Estado etno-

\footnotetext{
37 "The Committee on Legal Affairs and Human Rights, in a study of the concept of "nation" and its use in Europe based on data gathered from questionnaire replies from 35 national parliamentary delegations and on statements by experts in law and political science at a hearing it organised in Berlin on 7 June 2004, concluded that it was difficult, not to say impossible, to arrive at a common definition of the concept of "nation"” (pág. web citada).
} 
céntrico a otro multicultural, o mejor: de un Estado nacionalista (y por ende, de difícil revestimiento cívico) a otro plurinacional, como podría ser, justamente, el caso de España.

Por eso, quizá sería más bien preciso preguntarse por el sentido y posible pervivencia del Estado-Nación, un término compuesto que indica ya claramente la difícil soldadura de sus dos miembros (y eso que, por extraño que parezca, tan "nación una e indivisible" se quieren los Estados Unidos de América, la República Francesa o el Reino de España: una federación, un Estado centralizado y un Estado compuesto de comunidades autónomas).

Y por eso, también, resulta sorprendente que podamos encontrar algunos atisbos, si no de solución, sí de un planteamiento plausible del problema en un añejo ensayo de 1862, escrito polémica y directamente contra las concepciones liberales de Mill (y avant la lettre, de Renan). Se trata del celebérrimo Nationality, de Lord Acton ${ }^{38}$. Este inteligente antirrevolucionario comienza por denunciar la teoría de la nacionalidad, que para él es "más absurda y criminal" que la del socialismo. La razón aducida es contundente: esa teoría (digamos, el "nacionalismo") no buscaba la libertad ni la prosperidad de la sociedad, sino; "hacer de la Nación el molde y la medida del Estado". Algo que habría ocurrido por vez primera con el estallido de la Revolución Francesa: una "nacionalización" del Estado que habría tenido su preparación y su condición de posibilidad en el propio régimen absolutista francés, que sólo se cuidaba del Estado, mientras que los liberales parecen -dice-cuidarse tan sólo de los individuos; de este modo, lo que queda arrumbado es justamente aquello de lo que habla continuamente el revolucionario, a saber: la nación. De todas formas, sería conveniente guardarse de tildar apresuradamente de "reaccionario" a Lord Acton. Desde luego, él cree que el sentimiento unitario e identitario de nacionalidad nace con la Revolución. Pero eso no implica que antes de ella dirigieran los gobernantes su atención y cuidado al mosaico de naciones bajo el dominio absolutista: "Era el interés de las familias reinantes y no el de las naciones el que regulaba las fronteras, y la administración seguía por lo regular unas vías que ninguna relación tenían con los deseos populares".

¿Por qué, entonces triunfó la Revolución? La respuesta puede no ser enteramente convincente, pero puede que no resulte quizá del todo descabellada, a la luz de la devaluación actual de los Estados nacidos al calor revolucionario (pues bien podría decirse que la Restauración -fruto del Congreso de Viena de 1815- ha sido en definitiva una prolongación del nacionalismo estatista bajo otros medios). Y es que si la revolución triunfó, piensa Acton, fue porque: "enseñó al pueblo a considerar sus deseos y necesidades como criterio supremo del derecho" (It taught the people to regard

\footnotetext{
${ }^{38}$ Recogido en: J. E. E. D. Acton, Essays on Freedom and Power, Boston, The Beacon Press, 1948. Accesible en la Red: https://www.mtholyoke.edu/acad/intrel/history/acton/htm, y en muchas otras páginas, lo cual da una idea de su actualidad.
} 
their wishes and wants as the supreme criterion of right). Ciertamente cabe apreciar aquí algo del indeseable aroma que impregnará muchas páginas de Ortega y Gasset sobre las masas (pues, como sigue Acton: dado que cada facción apelaba a las masas como árbitro para poder estar en el poder, ello "las acostumbró a ser tan arbitrarias como insubordinadas").

Sin embargo, a pesar de ese ataque frontal a la soberanía del pueblo (¿dónde radicar, si no, la fuente del poder constituyente?), la condena del nacionalismo abstracto que Acton realiza -en favor, precisamente, de las nacionalidades- sigue dando qué pensar, al menos si tenemos en cuenta el reflejo que esa idea (y más, ese ideal) ha tenido en países invertebrados como España. He aquí la acusación: el título de "República Una e Indivisible [...] expresó, por vez primera en la historia, la noción de una nacionalidad abstracta" (Republic One and Indivisible [...] expressed, for the first time in history, the notion of an abstract nationality).

De seguir la tesis de Acton, el resultado de la erección de la Nation une et indivisible habría sido justamente la subordinación y hasta la destrucción de las nacionalidades (recuérdese lo beneficioso que, según Mill, habría sido para los vascos su integración en Francia -o añadiríamos, en España). Pues la doctrina nacionalista habría conseguido disolver los elementos naturales de la sociedad, "amenazando con despedazar el país en tantas repúblicas como individuos" (threatened to break up the country into as many republics as there were communes $)^{39}$.

Por ello, no es extraño que Acton encuentre el modelo de lo que debe constituir una sociedad civilizada justamente en el ejemplo denostado por Mill: en el Imperio Austro-Húngaro ${ }^{40}$. Ahora bien, lo que él valora para un espacio y un tiempo bien determinados de la historia europea cobra ahora, al fundirlo con los horizontes de la globalización y el localismo, un sentido claramente actual: "La coexistencia de varias naciones bajo el mismo Estado constituye una prueba (a test), así como la más alta seguridad de la libertad de esas naciones. Y es también uno de los instrumentos capitales de civilización; en cuanto tal, se halla dentro del orden natural y providencial, e indica una situación de mayor progreso que la unidad nacional, el ideal del liberalismo moderno”. ¿Por qué? Porque, según Acton, el liberalismo (diríamos: un

\footnotetext{
${ }^{39}$ Recuérdese lo que había señalado Montesquieu al hablar de la nación de notables: que todavía no existía el problema de los communes (ver supra, nota 26).

${ }^{40}$ Es interesante observar que también Paul Celan conserva un cálido recuerdo del Imperio AustroHúngaro, al cual pertenecía la Bucovina natal: "El paisaje del que yo vengo -dice- [...] era un lugar en el que vivían hombres y libros. Allí, en aquella antigua provincia de la monarquía habsbúrgica, ahora relegada a la ahistoricidad (der Geschichtslosigkeit anheimgefallenen), ..." Ansprache anlässlich der Entgegennahme des Literaturpreises der freien Hansestadt Bremen. En: Gesammelte Werke, Frankfurt/M., Suhrkamp, 1992²; III, 185. Ocioso es decir, como compensación, que Robert Musil no pensaba lo mismo de su Kakanien. Sobre este tema, ver: Claudio Magris, Der habsburgische Mythos in der österreichischen Literatur, Salzburg, Otto Müller, 1966.
} 
nacionalismo identitario apoyado en la razón de Estado) impide a radice la fertilización interracial e intercultural. Y es que, según Acton, mientras el Estado-Nación tiende a la uniformidad estéril, los estados e imperios multinacionales generan diversidad y armonía. Como si se tratara de una premonición de las críticas de Hannah Arendt al marxismo ${ }^{41}$, Acton insiste en que lo que ha de ser buscado y fomentado es la libertad, no la igualdad. Por cierto, es Suiza el modelo que él tiene en mente (como también lo es, por otras razones, para el propio Mill).

¿Es posible volver atrás? No, no es posible. Ni deseable. Pero la disyuntiva que, en conclusión, nos propone Acton sigue dando qué pensar. Pues las salidas de un EstadoNación que -vemos ahora- apenas puede seguir perviviendo, parecen ser sólo dos, según Acton: si un país extenso quiere conservar su autogobierno (el ideal defendido también por Mill), dice, si quiere seguir siendo: "una gran democracia, o bien debe sacrificar el autogobierno por mor de la unidad, o preservarlo por el federalismo" (a great democracy must either sacrifice self-government to unity, or preserve it by federalism).

Así expresada, con todo su dramatismo, la disyuntiva bien puede servir para retornar a la difícil cuestión que se dejó planteada, a saber: si España es una nación en el sentido liberal, en el sentido de Mill o Renan, es decir: una comunidad soberana, con un régimen político representativo y de autogobierno, y que se mantiene unida por la voluntad de sus miembros, amparados por una ley común de la que se sienten partícipes aun sin haber intervenido directamente en ella; o si es más bien una nacionalidad que se asemejara a un organismo viviente y procesual, crecido y madurado en la lenta formación histórica de un pueblo ligado a un territorio, con lengua común y tradiciones, con usos y costumbres compartidos, en el sentido de Lord Acton. Mi respuesta, por tentativa que sea, no puede ser más decepcionante (también para mí, desde luego). Creo que, dejando aparte disquisiciones esencialistas sobre el "ser" de España, un somero examen de las vicisitudes políticas y culturales del uso del término, a partir de la Revolución Francesa y de la llamada invasión napoleónica, deja ver que políticos, eruditos, historiadores e ideólogos varios intentaron (y de algún modo siguen intentando) zanjar la disyuntiva entre, por decirlo kantianamente, un Estado con constitución republicana, y una Nación como organismo secular, creciendo quasi biológicamente, como por preformismo. La solución era obvia, y es la que siguieron muchos estados europeos en el siglo XIX: bastaría con unir los dos términos: por caso, la grandeur de la France y la République une et indivisible. Sólo que en España esa fusión no se logró, y creo que tampoco ahora se ha conseguido; ahora, tras la Constitución de 1978, y cuando seguramente es ya tarde para hablar de estados nacionales soberanos.

${ }^{41}$ Cf. Hannah Arendt, Karl Marx and the Tradition of Western Political Though. SOCIAL RESEARCH 69/2 (Summer2002) 273-319. Hay tr. esp. (ed. de A. Serrano de Haro), Madrid, Encuentro, 2007. 


\section{Una Constitución pactada para una Nación frustada}

Empecemos por el final: la Constitución de $1978^{42}$ está dividida en 10 Títulos y 169 artículos. Pues bien, el término "nación" aparece dos veces, mientras que el de Estado tiene 90 entradas. La primera y más importante mención es aquella con la que se abre el Preámbulo, como si, con rotunda prosopopeya, fuera la Nación misma la que redacta la Constitución: "La Nación española, deseando establecer la justicia, la libertad y la seguridad y promover el bien de cuantos la integran, en uso de su soberanía, proclama su voluntad...”. De seguir la letra misma: la Nación es un organismo, porque tiene "deseos"; es además racional y benevolente para con los miembros que la integran (articulatio): no se trata pues de un mero acúmulo o agregado (coacervatio per appositionem), sino de una totalidad viviente, per intus susceptionem ${ }^{43}$. Por último, expresa su voluntad, autoconstituyéndose como "Estado social y democrático de derecho" (Título preliminar; art. 1.1) al desplegar todos sus órganos y funciones.

Por otra parte, la alusión a "cuantos la integran" parece referirse desde luego a individuos. En efecto, el art. 2 fundamenta la Constitución en: "la indisoluble unidad de la Nación española, patria común e indivisible de todos los españoles". (Por cierto, ésta es la segunda y última mención del sustantivo, mayestáticamente encumbrado). Implícitamente se define aquí "patria" como el vínculo vital de adunamiento de un conjunto de individuos con un Organismo Nacional, cuyos miembros, a su vez, constituyen una manera harto extraña, admítase, de fundir o confundir la "nación" en el sentido liberal, atomístico, con el orgánico (adviértase, contra Renan, que no son los miembros los que deciden o desean tal o cual cosa, sino la Nación: ella es la que detenta la soberanía, no el pueblo; y quien hace saber esa proclamación de soberanía no es tampoco el pueblo, sino la personificación de la Nación misma: el Rey de España, que es el que hace saber urbi et orbi aquello que "las Cortes han aprobado y el pueblo ratificado"). De modo que, contra lo explícitamente señalado, no se trataba de individuos (por así decir, sueltos), sino del "pueblo", dividido y agrupado al punto, según lo prescribe y proclama la Nación.

\footnotetext{
42 Pueden encontrarse muchas páginas web que recogen el texto constitucional. P. e.: www.derechoshumanos.net/.

${ }^{43}$ Podemos aplicar muy bien a esta concepción política estas distinciones biológicas, al igual que Kant las tomara para describir el conocimiento científico: "El todo consta pues de miembros (articulatio), no de cosas sueltas (coacervatio); en verdad, puede crecer internamente (per intus susceptionem), pero no externamente (per appositionem), al igual que un cuerpo animal, para cuyo crecimiento no viene añadido ningún miembro, sino que, sin variar la proporción, hace que cada uno de ellos llegue a ser más vigoroso y capaz." ("Die Architektonik der reinen Vernunft": Kritik der reinen Vernunft A 833/B 861).
} 
En efecto, ese mismo artículo 2 del Título preliminar continúa afirmando que la Constitución: "reconoce y garantiza el derecho a la autonomía de las nacionalidades y regiones que la integran y la solidaridad entre todas ellas" (subr. mío). El punto es objeto continuo de litigio, y con razón. En primer lugar, queda confuso qué es aquello que "integra" a la Nación. Las ya citadas palabras liminares del Preámbulo parecen referirse a individuos (se dice: "cuantos la integran", en masculino). Pero, ahora, los miembros son "nacionalidades y regiones" (en femenino, de manera que no hay posibilidad de conexión). Claramente, lo primero quiere conciliar la Constitución con la idea "liberal", pero con alusiones claramente organicistas; lo segundo, en cambio, parece arrimarse a la idea "organicista", mientras que el reconocimiento del "derecho de autonomía", remite en cambio a la idea liberal. Un cruce, como se ve, poco satisfactorio en los dos casos.

Por otra parte, la alusión a las "regiones" apunta a la vieja idea de la división territorial de un reino. Esta palabra, por cierto, no se menciona en parte alguna en la Constitución: cosa extraña, dado que España se configura, en su forma imperii, como Reino ${ }^{44}$. Reino de España, en singular. Pero entonces, ¿qué o quiénes son las "nacionalidades"? ¿Qué quiere decir, o más bien qué oculta este término, utilizado como vimos por Lord Acton para referirse a esas entidades orgánicas, etnoculturales? Es evidente que se trata de un púdico expediente para aludir, sin nombrarlos, a los antiguos reinos de España, aparte de Castilla (cuyas serían en cambio las "regiones") ${ }^{45}$, Galicia, el País Vasco y Andalucía ${ }^{46}$. Y bien, ¿cuál es el sentido y función de regiones y nacionalidades? Imposible saberlo, ya que esos términos no vuelven a aparecer en la Constitución. Vuelve a mentarse, sí, la "nacionalidad", pero como la cualidad propia de haber nacido en España (Art. 11: "nacionalidad española"), o en otro país (Art. 149). Así que la Nación está integrada por dos "entidades" literalmente indefinidas. En cambio, el Título VIII ("De la organización territorial del Estado"), Cap. $1^{\circ}$, art. 137, reza: "El Estado se organiza territorialmente en municipios, en provincias y en las Comunidades Autónomas que se constituyan. Todas estas entidades gozan de autonomía para la gestión de sus respectivos intereses". Que las Comunidades Autónomas corresponden a esas "regiones y nacionalidades"

\footnotetext{
${ }^{44}$ Ciertamente, en el Tratado preliminar (art. 1.3) se dice: “3. La forma política del Estado español es la Monarquía parlamentaria".

${ }^{45}$ Desde finales del siglo XII, la península estaba dividida en cinco reinos: Granada (musulmanes), León con Castilla, Navarra, Portugal y la Corona de Aragón (cristianos). Tras el breve período de anexión de Portugal (1580-1640), y hasta el advenimiento de los Borbones, España estaba dividida pues en tres reinos: Castilla, Navarra y Aragón.

${ }^{46}$ Ésta última, por cumplir lo exigido en el art. 151.1, aunque no parece que los diversos partidos que en han gobernado como "Junta" de Andalucía, hayan mostrado excesivo interés en considerarla "nacionalidad".
} 
es patente por el art. 138, que remite al art. 2, pero en lo relativo a la "solidaridad" entre comunidades ${ }^{47}$.

¿Qué ha ocurrido aquí? La Nación se presenta, primero, como Una e indivisible. Pero al punto reconoce estar integrada por dos entidades diversas, lo cual implica una desigualdad. Ésta, sin embargo, es reconducida a la igualdad, al hacer de "regiones y nacionalidades" comunidades autónomas solidarias. Las razones de este retorno a la identidad mediante la conversión de la diversidad a igualdad habrían suscitado seguramente la cólera de Hegel. Sólo que esas razones no son desde luego lógicas, sino históricas.

Contra lo repetido ad nauseam durante la dictadura franquista, los Reyes Católicos no unificaron España como un Estado integral. En verdad (tal es, obviamente, la tesis de este trabajo) nunca ha existido de facto una Nación española (integradora de regiones y nacionalidades, como quiere creer la Constitución actual). Ni siquiera es seguro que se haya consolidado nunca como Estado-Nación, en el sentido moderno. Veámoslo brevemente.

La llamada Monarquía Hispánica (fundamentalmente, la Casa de Austria, o sea la rama española de los Habsburgo) constituyó ciertamente un Estado absolutista, restringiendo el poder de la nobleza y organizando su gobierno en torno a cinco Consejos de Estado: Castilla, Aragón, Italia, los Países Bajos, Portugal (entre 1580 y 1640) y América (Consejo de Indias). El elemento real de cohesión era la lealtad al Rey, junto con la forzosa adscripción a la religión católica; el ideal de unificación lingüística (quizá acariciado por Nebrija) en el mal llamado "Imperio" nunca se ha logrado por entero, ni siquiera durante la larga noche franquista. Así pues, los distintos reinos de la múltiple Corona (las "Españas") mantenían administración, moneda y leyes propias. El dominio de los Austrias correspondería muy bien, según esto, al ideal defendido por Lord Acton. En ese sentido, se trataría de una especie de "confederación de nacionalidades", que conservan sus peculiares fueros y tradiciones.

Por otra parte, el predominio de Castilla (aglutinando Galicia, Asturias y León) sobre los demás reinos era evidente por extensión y población, y más tras incorporar las Indias a la corona castellana a título de "descubrimiento" (res nullius). Ello no obstante, será el Consejo de Indias y no el de Castilla el que asesore al rey sobre las nuevas tierras.

\footnotetext{
${ }^{47}$ En la Constitución de la Segunda República (1931), el intento de convertir a España en un "Estado integral" y de unificar todas las comunidades bajo el rótulo "provincias y regiones" (arts. 1,4 y 8) es patente. De 125 artículos, el término "Nación" sólo aparece en 8 ocasiones (arts. 45, 53, 67, 76 d) y e), 77 y 117). Las menciones más importantes están en el art. 53 (“Los Diputados [...] representan a la Nación") y en 67 ("El presidente de la República es el Jefe del Estado y personifica a la Nación"). Sólo en estos casos aparece España, simbólicamente, como una suerte de viviente "individuo colectivo". El país se define como una "República democrática de trabajadores" (art. $\left.1^{\circ}\right)$.
} 
Esa pluralidad, no sin sobresaltos ${ }^{48}$, derivó hacia una mayor centralización tras la Guerra de Sucesión y la subsiguiente entrada de la dinastía borbónica en España. De 1707 a 1716, el nuevo rey: Felipe V, fue publicando los llamados "decretos de Nueva Planta", relativos - pero en cada caso diferentes-a los antiguos reinos y posesiones de la Corona de Aragón. Como castigo por su rebelión, y por derecho de conquista, el Rey Borbón deroga parte de los fueros y derechos de los territorios de la Corona de Aragón, sobre los que considera tener derecho de conquista $^{49}$. En cambio, esa pérdida de

${ }^{48}$ El primer intento de proclamar una república en la Península se remonta a 1641, cuando Pau Claris, Presidente de la Generalidad de Cataluña, proclamó la República Catalana el 17 de enero de 1641. Una semana después, al entrar en el Principado el ejército de Felipe IV, Claris proclamó a Luis XIII de Francia Conde de Barcelona (Luis XIV lo sería después, de 1643 a 1652). La Paz de los Pirineos (1659) puso fin al conflicto, en detrimento de España... y de la propia Cataluña, ya que Francia se quedó con los territorios del antiguo Condado del Rosellón y con la parte norte del de la Cerdaña, invalidando así las demarcaciones establecidas por las Constituciones de Cataluña. ${ }^{49}$ Sobre el recuerdo de la capitulación de la ciudad de Barcelona (11 de septiembre de 1714), el nacionalismo catalán erige la reivindicación de la independencia de Cataluña (por eso se celebra la Diada cada 11 de septiembre), interpretando que, entonces, una Cataluña vencida se vio incorporada por la fuerza a la Corona de España, gracias a la unión de los ejércitos francés y español frente a la coalición de los defensores de Carlos, Archiduque de Austria, que aspiraba a suceder en el trono a Carlos II. Sin embargo, es preciso señalar que dicha interpretación es, cuando menos, sesgada. Como se desprende palmariamente del pregón de Rafael Casanova (Conseller en Cap de la Ciutat de Barcelona), lo que ardientemente se deseaba era la continuidad de la dinastía de los Austria en España (y con ello, el mantenimiento de los fueros y tradiciones de Cataluña, dentro de la Monarquía Hispánica), a fin de evitar la dependencia de España de la pujante Francia del Rey Sol, abuelo de Felipe V, con el consiguiente cambio de dinastía (una dependencia que, por lo demás, setenta años atrás había sido ofrecida por la nonata República Catalana; ver nota anterior). Es por la España de los Austria por lo que Casanova exhorta a la lucha final del pueblo reunido; o bien, si el bando no obtiene el efecto deseado, a una honrosa rendición de la ciudad para evitar mayor derramamiento de sangre. Pues, como se dice en el pregón, lo que los "tres Excms. Comuns, pres lo parer dels Senyors de la Junta de Gobern" ("tres Excelentísimos Comunes [Alcaldías] , tomado el parecer de los Señores de la Junta de Gobierno") pretenden evitar, o al menos paliar, es "la deplorable infelicitat de esta ciutat, en que avuy resideix la llibertat de tot lo Principat y de tota Espanya" ("la deplorable infelicidad de esta ciudad, en la que hoy reside la libertad de todo el Principado y de toda España"; subr. mío). Y aunque los Comunes declaran y dan testimonio de haber realizado todos los esfuerzos por salvar a la ciudad de "las armas gali-spanas", no pueden dejar de lamentarse: "de tots los mals, ruinas y desolacions que sobrevinguen á nostra comuna y afligida patria, y estermini de tots los honors y privilegis, quedant esclaus ab los demés enganyats espanyols y tots en esclavitud del domini francés; pero com tot se confía, que tots com verdaders fills de la paria, amants de la llibertat, acudirán als llochs senyalats á fin de derramar gloriosamente sa sanch y vida, per son Rey, per son honor, per la patria y per la llibertat de tota Espanya" ("de todos los males, ruinas y devastaciones que le acaecen a nuestra afligida patria común, así como de la extinción de todos los honores y privilegios, quedando esclavos con los demás engañados españoles, y todos esclavizados por el dominio francés; pero, con todo, se confía en que todos, como verdaderos hijos de la patria y amantes de la libertad, acudirán a los sitios señalados 
autonomía no afectó al Valle de Arán, ni tampoco a Navarra ni a las Provincias Vascongadas, que mantuvieron todos sus fueros por haber permanecido leales al Duque de Anjou. De este modo, la España borbónica se convierte en una monarquía absoluta fuertemente centralizada. Se crean las Secretarías de Despacho, antecedentes de los ministerios. Y en 1787 se establece la Junta Suprema de Estado, antecedente del Consejo de Ministros. Lo más relevante: quedan suprimidos los Consejos, salvo el Consejo de Castilla, que se convierte en el órgano asesor del rey. Bien puede decirse que aquí tiene su inicio el intento posterior de hacer de Castilla el gran factor aglutinante de las Españas. Como afirma el propio Felipe V en 1707: "He juzgado por conveniente [...] reducir todos mis Reynos de España a la uniformidad de unas mismas leyes, usos, costumbres y Tribunales, gobernándose todos igualmente por las leyes de Castilla".

Así, como resultado de una represión y por derecho de conquista, una España castellanizada a la fuerza comienza a estar configurada como si se tratara de un moderno Estado (de importación francesa) nacional (de exportación castellana). Naturalmente, la ilusión duró bien poco. El gran ilustrado José Marchena (llamado el Abate Marchena, aunque nunca fue miembro del clero), entre otras cosas traductor de Le contrat social de Rousseau y del De rerum natura de Lucrecio, y exiliado en Bayona para escapar de la Inquisición, escribe en 1792 un revelador informe para JacquesPierre Brissot, girondino y ministro de asuntos exteriores de la República, sobre las dificultades para implantar en España una Constitución semejante a la francesa de 1791: "La France a adopté une constitution qui fait de cette vaste nation une république une et indivisible. La conformité dans les moeurs, les lumières presqu'également répandues dans toute sa surface la font propre à cette institution. Mais l'Espagne, dont les diverses provinces ont des moeurs et des usages très différents, l'Espagne, à laquelle le Portugal doit être réuni, ne doit former qu'une république fédérative. On peut donc laisser subsister les différentes Cortes, et on le doit même, pour le bonheur de cette nation"50. Y en verdad fue escuchado el consejo del Abate Marchena. En la que puede considerarse primera Constitución española: el Estatuto de Bayona (en

a fin de derramar gloriosamente su sangre y su vida por su Rey (el Archiduque Carlos), su honor, la patria y la libertad de toda España."; subr. mío). (El texto, ahora presente en varias págs. web, fue recogido por José Coroleu y José Pella y Forgas en Los Fueros de Cataluña, Barcelona, 1878, p. 689). El pregón no tuvo desde luego el efecto deseado y, por ende, la ciudad hubo de capitular. Añadiré que, seguramente, las alusiones a la "patria" corresponden a Cataluña (aunque llama la atención que se hable de "patria común"); pero no hay duda del deseo de seguir perteneciendo a España (a la España de los Austrias, ciertamente), hasta el punto de disculpar incluso a los partidarios de la dinastía borbónica, es decir, a "los demás engañados españoles".

${ }^{50}$ En: Alfred Morel-Fatio, "José Marchena et la propagande révolutionnaire en Espagne en 1792 et 1793", Revue historique, XLIV (1890), 79 (cit. en: Xavier Arbós Marín, Doctrinas constitucionales y federalismo en España, W[orking] P[apers] núm. 245, Barcelona, Institut de Ciències Polítiques i Socials, 2006, p. 6, n. 4). 
francés: Acte Constitutionnel de l'Espagne), de 6 de julio de $1808^{51}$, era ciertamente una Carta otorgada, dictada, digamos, por Napoleón a 91 diputados reunidos en la ciudad francesa. En ella llama poderosamente la atención la defensa exacerbada de la religión católica (el Título I, art. 1, trata precisamente "De la Religion"; siendo la confesión católica "la religión del Rey y de la Nacion"), quizá como contrapeso a la aceptación del carácter plural del país (se habla de la "Corona de las Españas y de las Indias": Titulo II, ar. 2), aunque se hace notar ya la insistencia en el carácter nacional (el art. VI señala que ha de gobernarse "solamente con la mira del interés, de la felicidad y de la gloria de la nación española"); y para encaminarse hacia esa unitariedad se dan algunos pasos importantes; por ejemplo, se suprimen las aduanas interiores (art. 116) y se emplaza a la creación de un solo código de leyes civiles y penales, así como de un código de comercio para España y las Indias.

Esta oscilación entre la unidad de la Nación (prudentemente sustituida la mayoría de las veces por la unidad de la Monarquía ${ }^{52}$ ) y la pluralidad de las "nacionalidades" se aprecia también en el libelo Centinela contra franceses, de Antonio de Capmany ${ }^{53}$, un ilustre político conservador, que con Argüelles y Creus Martí participó en la Junta Especial de Inspección de la Constitución de 1812. Mientras que Marchena advertía a Brissot del carácter plural de los pueblos de España, Capmany hace lo propio, pero justamente para dirigir su poderosa retórica contra la invasión napoleónica y elogiando la intervención inglesa en términos -diría Ortegade veras estupefacientes. En efecto, el libro está dedicado: "Al Excmo. Señor D. Henrique Holland, Lord de la Gran Bretaña", y en esa dedicatoria exalta el autor "la lealtad española, [que] abrió á la generosidad inglesa el gran teatro de esta penín-

\footnotetext{
${ }^{51}$ Puede consultarse el texto en: http://www.cervantesvirtual. com/servlet/SirveObras /02585178888 236328632268/p0000001.htm.

${ }^{52}$ De las nueve constituciones españolas habidas en el siglo XIX, todas ellas (incluida la de 1812) afirman ser: "Constitución de la Monarquía". Sólo una declara desde el inicio el carácter nacional de España: la "Constitución democrática de la Nación española”, de 1869; la constitución abortada de 1873, la más progresista, presentada como: "Proyecto de Constitución Federal de la República Española", será sustituida por la de 1876, producto de la Restauración, y denominada de nuevo: "Constitución de la Monarquía". Por cierto, parece que jurídicamente esa Constitución no habría podido ser derogada ni por la de 1931 (por ser ésta el resultado de elecciones municipales, y de la ulterior huida de Alfonso XIII) ni tampoco por el golpe de estado franquista, presuntamente refrendado y legalizado en 1958 (Ley de Principios del Movimiento Nacional) y 1967 (Ley Orgánica del Estado). De modo que, al menos desde el punto de vista de la legitimidad, esa Constitución ha sido la más duradera de toda la historia de España (más de 100 años), sin haber sido suprimida hasta la Constitución de 1978 (véase el punto 2 de la Disposición derogatoria: "se considera definitivamente derogada la Ley de 21 de julio de 1876").

${ }^{53}$ La primera parte se concluyó el 15 de septiembre de 1808 (Madrid, Gomez Fuentenebro y Compañía, 1808; hay ed. actual de J. Lainz, Madrid, Encuentro, 2008; pero se cita en el texto por la edición original, recogida en www.books.google.com/books/about/Centinela_contra_franceses/html).
} 
sula, en donde pueden brillar el valor y el honor de entrambas naciones, pues hay campo para todas".

Se han cambiado pues las tornas: Napoleón es vilipendiado como invasor y en cambio se saluda a la Gran Bretaña como "liberadora". Pero la temática de las "nacionalidades" sigue significativamente la misma senda que Marchena. Francia es unitaria; España, plural... para su bien (por cierto, las vigorosas expresiones de Capmany permiten suponer que éste había leído las Reflections on the French Revolution, de Edmund Burke): "En Francia, pues, no hay provincias ni naciones; no hay Provenza ni provenzales; ni Normandía ni normandos: se borraron del mapa sus territorios, y hasta sus nombres. Como ovejas, que no tienen nombre individual, sino la marca común del dueño, les tiene señalados unos terrenos acotados, ya por riberas, ya por ríos, ya por sierras, con el nombre de departamentos, como si dixéramos, dehesas; y estos, divididos en distritos, como si dixéramos majadas. Allí no hay patria señalada para los franceses, porque no tiene nombre la tierra que les vió nacer, ni la del padre que los engendró, ni de la madre que los parió. (...) Todos se llaman franceses, al montón, como quien dice carneros bajo la porra del gran rabadán imperial” (op. cit., p. 92).

Por cierto, no deja de ser incoherente el que se reniegue de esa denominación genérica mientras se aplica, en cambio, el nombre común de "españoles" a una serie de pueblos, enumerados también al montón, pero (y esto es lo relevante) denominados ya como pequeñas naciones: “QQué sería ya de los españoles si no hubiera habido Aragoneses, Valencianos, Murcianos, Andaluces, Asturianos, Gallegos, Extremeños, Catalanes, Castellanos, etc.? Cada uno de estos nombres inflama y envanece y de estas pequeñas naciones se compone la masa de la gran Nación, que no conocía nuestro conquistador" (p. 94). Naturalmente, no se dice cómo sea posible componer esa "masa". Capmany se limita a afirmar solemnemente (como si se anticipara a Lord Acton): "la civilización mata a las naciones" (p. 137).

Más adelante, y en el colmo de la incoherencia, será el mismo Capmany quien rechace de un modo vehemente el principio federativo, negando la existencia política de otra nación, salvo la española: "Nos llamamos Diputados de la Nacion, y no de tal o cual provincia: hay diputados por Cataluña, por Galicia, etc.; mas no de Cataluña, de Galicia, etc.; entonces caeríamos en el federalismo, o llámese provincialismo, que desconcertaría la fuerza y concordia de la unión, de la que se forma la unidad"54.

Ciertamente, la Constitución de $1812^{55}$, alabada por tantos motivos, sigue mostrando la misma querencia afrancesada por el unitarismo, y tiene buen cuidado desde luego en evitar toda concesión al "federalismo o provincialismo", como si los anti-

\footnotetext{
${ }^{54}$ Intervención de Capmany el 21 de enero de 1813. Diario de sesiones de las Cortes generales y extraordinarias, vol. VI, p. 4421. Cit. en Arbós, op. cit., p. 8, n. 8.

${ }^{55}$ Puede consultarse el texto en: www.congreso.es/constitucion/ficheros/historicos/cons_1812.pdf.
} 
guos reinos pudieran ser degradados ipso facto por decreto a meras provincias. Es importante advertir que, para asegurar esa uniformidad del país, la Nación sigue confiando fundamentalmente en la Corona. La Constitución de 1812 (cariñosamente llamada "La Pepa", por haber sido promulgada el 9 de marzo, día de San José, mas también para burlarse de Josef Bonaparte, el rey impuesto) es denominada "Constitución política de la Monarquía española”, y no de la nación. Y desde luego sigue sin tener claro cómo denominar a España y cuál sea su régimen; pero lo que le importa es subrayar el carácter singular de la constitución del país, haciendo abstracción de pueblos, razas, culturas y tradiciones. De este modo, como si los Diputados de las Cortes de Cádiz estuvieran señalando el camino a John Stuart Mill, el artículo $1^{\circ}$ reza: "La Nacion española es la reunion de todos los Españoles de ambos hemisferios" Y antes, en el Preámbulo (en donde se mezclan por cierto nombre y forma; y, dentro de ésta, forma regiminis y forma imperii) se dice en efecto: "Las Cortes generales y extraordinarias de la Nacion española bien convencidas [...] de que las antiguas leyes fundamentales de esta Monarquía, acompañadas de las oportunas providencias y precauciones [...] podrán llenar debidamente el grande objeto de promover la gloria, la prosperidad, y el bien de toda la Nacion, decreta la siguiente Constitución política para el buen gobierno, y recta administración del Estado" (subr. mío). Los cuatro primeros artículos del Capítulo $1^{\circ}$ del Título $1^{\circ}$ ("De la Nacion Española y de los Españoles") repiten insistentemente el término en su articulado, mientras que el problema fundamental: el carácter, sentido, función y alcance de las "pequeñas naciones" que debieran integrar la Nación queda mentado (y sólo eso) en el art. 11, que anuncia "una división mas conveniente del territorio Español por una ley Constitucional, luego que las circunstancias políticas de la Nacion lo permitan". Por cierto, hoy sabemos que esa división estaba ya articulada desde octubre de 1808, pero que no se dio a conocer públicamente, seguramente por temor a que todas esas bravas "pequeñas naciones" cantadas por Capmany decidieran no componer la "masa de la gran Nacion" en su lucha contra el francés (mientras que, tácitamente, ya en 1808 se estaba haciendo tabla rasa, muy à la française, de las "antiguas leyes fundamentales", tan alabadas luego en la Constitución) ${ }^{57}$.

\footnotetext{
${ }^{56}$ En el art. 13 (Cap. $3^{\circ}$, "Del Gobierno") se insiste en la misma abstracción, identificando al efecto Nación, sociedad política y conjunto de individuos: "El objeto del Gobierno es la felicidad de la Nacion, puesto que el fin de toda sociedad politica no es otro que el bien estar de los Individuos, que la componen".

${ }^{57}$ El diario ABC publica el 25 de septiembre de 2008 un artículo firmado por Tulio Demicheli, en el que éste da cuenta del descubrimiento realizado por el historiador Emilio de Diego, al examinar los archivos de Martín de Garay: unos "documentos muy poco conocidos en los que se hace la primera mención expresa a la Nación”. Explica De Diego: "Se trata del Reglamento para la Junta [i.e., la Junta Suprema Central y Gubernativa del Reino, reunida en Aranjuez], que se redactó en octubre de 1808, cuyo Capítulo III se refería a los vocales y en su Artículo I se especifica que los
} 


\section{Del fracaso de un buen proyecto}

Dadas todas estas ambigüedades, no es de extrañar que, durante todo el siglo XIX, la cuestión territorial (entrelazada con la no menos célebre "cuestión social") siguiera constituyendo un grave problema para la deseada estructuración de un país que estaba dejando progresivamente de ser un Imperio (sin que legalmente nunca reconociera esa situación), pero sin llegar a constituirse (entre asonadas, pronunciamientos, intrigas de palacio y cambios de régimen, y hasta -por brevísimo tiempode dinastía) en un verdadero Estado-Nación.

De entre todo ese alboroto se alzó una voz serena y ecuánime (que, como cabe suponer, no fue apenas escuchada): la de Don Francisco (o Francesc) Pi y (i) Margall, que tras Estanislao Figueras (bajo cuyo mandato fue Ministro de la Gobernación) fue efímero segundo Presidente de la Primera República Española (del 11 de junio al 18 de julio de 1873$)^{58}$. Pi ha sido seguramente el mejor representante del federalismo español en general ${ }^{59}$.

Este excelente pensador político, que tan bien conocía las ideas de Proudhon y era un gran admirador de $\mathrm{Hegel}^{60}$, ha realizado las propuestas posiblemente más lúcidas

vocales de la Junta Suprema Central y Gubernativa del Reino, reunidos en cuerpo, representan a la Nación entera, y no individualmente a las provincias de las que son diputados." El historiador añade, con solemnidad: "Por primera vez en nuestra historia se está diciendo que ésta no es la España de los Reinos, sino la España de la Nación. Además, ya se señala, antes de la Constitución de 1812, que la soberanía reside en la Nación, no en sus partes".

${ }^{58}$ En puridad, Pi i Margall se hizo cargo del poder ejecutivo de la República en ese breve período. Legalmente no podía ser Presidente mientras no se promulgara una nueva Constitución (el muy notable Proyecto republicano de Constitución de 1873, alentado por él, nunca fue llevado a cumplimentación). Pi hubo de retirarse del puesto, incapaz de acabar de un lado con los levantamientos cantonalistas, como el famoso de Cartagena (que era el resultado de una lectura extremada del ideal federalista), y de conciliar del otro la división en las propias files republicanas, escindidas por una parte entre unionistas y federalistas -divididos a su vez en moderados y radicales-, por lo que hace a la cuestión territorial, y entre socialistas e individualistas en la cuestión social.

${ }_{59}$ Actualmente, el PSOE propugna un nuevo federalismo, como ha quedado plasmado en el documento: Hacia una estructura federal del Estado, del Consejo Territorial (Granada, 6 de julio de 2013; el documento puede obtenerse a partir de EL PAIS.es, de 7 de julio de 2013). Pero ni siquiera en las filas socialistas hay unanimidad al respecto: mientras que el PSC (Partit Socialista de Catalunya) interpreta la propuesta de que las Comunidades se denominen según sus respectivos Estatutos en el sentido de que Cataluña, en consecuencia, debería ser reconocida como "nación", el PSOE niega resueltamente esa posibilidad. También promete una mayor autonomía (con especial mención a Andalucía), y defender y promocionar la lengua propia de las comunidades históricas, así como convertir el Senado en una Cámara territorial (algo que ya prometiera, en vano, el expresidente Rodríguez Zapatero, en su discurso de investidura de 2004). Y poco más, salvo una apelación bienintencionada a la solidaridad entre comunidades.

${ }^{60}$ Sobre el influjo del hegelianismo en Pi llamó hace tiempo la atención Pierre-Luc Abramson, en 
en pro de la erección de una nación (todavía) inexistente. Pero no se trata de ejercitar el juego de la nostalgia y de traer a colación posibles contrafácticos (del tipo: ¿existiría hoy el nacionalismo separatista catalán de haber germinado la idea federal de España que tenía Pi?), sino de recontextualizar brevemente en una fusión de horizontes las concepciones del político catalán, con vistas a una mejor comprensión (no directamente solución) de la espinosa cuestión territorial española.

Para empezar, y salvo querencias ideológicas extremosas, es difícil no aceptar la tesis de Pi sobre lo que podríamos llamar "la concepción heredada" del concepto de Nación; como hemos tenido ocasión de comprobar, ese modelo imponía un centralismo uniformador (que ahora, por cierto, se pretende revitalizar desde la derecha españolista), convirtiendo metonímicamente una (empobrecida) Castilla en el modelo (soñado) de España (pars pro toto): "Esta unidad ¿qué ha traído generalmente sino males? Ha concentrado casi siempre la vida en la metrópoli, ha absorbido la de las colonias, las ha muerto. Ha apagado mil focos de actividad, ha destruido mil elementos de progreso... Ha empobrecido y degradado las comarcas subyugadas." Tal es el diagnóstico. La propuesta de curación, el federalismo.

Es cierto que, a las veces, Pi parece caer en la órbita del organicismo (al cabo, sentía un gran aprecio por Darwin), al considerar a las naciones como "unidades orgánicas". Ahora bien, si queremos seguir con el símil biologicista, habría que hablar en su caso más de epigénesis que de preformismo. Pues, lejos de todo esencialismo, Pi afirma que las naciones son: "Seres colectivos y libres, [que] tienen todas distinta organización, y la cambian según las evoluciones de las ideas y las necesidades de los tiempos... Se quiere hacer hoy a las naciones poco menos que ídolos. Se las supone eternas, santas, inviolables; se las presenta como algo superior a la voluntad, como esas formaciones que vemos en la naturaleza, obra de los siglos"61. Ello no obstante, es cierto que, si no la nación, sí desde luego la sociedad era considerada por Pi "como una realidad orgánica, previa a los hombres, y sólo por eso estaba garantizada la cooperación del individuo incluso sin poder" ${ }^{2}$. Extraño organicismo éste, más de tipo normativo y, casi diríamos, performativo, que biológico. Pero desde luego, saludable en un momento en que las ideas racistas del Conde de Gobineau estaban envenenando mentes y pueblos ${ }^{63}$.

\footnotetext{
un breve pero documentado artículo: L'État dans la pensé politique de Francisco Pi y Margall (Actes du Colloque de Rennes 21-22 avril 1988, recogidas en el vol. colectivo: État, révolutions, idéologies, Presses.Univ. de Aix-Marseille, 1989, pp. 5-11). Recientemente ha insistido en el tema Jorge Cagiao y Conde: A vueltas con el federalismo español: Pi y Margall, Proudhon y Hegel. En: Cahiers du civilisation espagnole contemporaine 2 (2008). On line: http.//ccec.revues.org/ 1443 ;DOI : 104000/ccec.1443.

${ }^{61}$ Lecciones de federalismo, Barcelona, Seguí, [1930?], p. 59.

62 J. L. Villacañas, La idea federal de España. En: Manuel Chust (ed.), Federalismo y cuestión federal en España, Castellón, Universitat Jaume I, 2004, pp. 115-160 (aquí, p. 127).

${ }^{63}$ Ver : Joseph-Arthur (Comte de) Gobineau, Essai sur l'inégalité des races humaines (1853-1855) (Éd. Pierre Belfond), Paris, 1967.
} 
Como ha señalado certeramente Ramón Máiz, en su extenso estudio introductorio a la obra capital de $\mathrm{Pi}$, Las nacionalidades: "Para Pi son las naciones procesos políticos de construcción nacional, no objetos cristalizados de una vez para siempre en el pasado. De este modo se elude el doble escollo: de un lado reducir la nación al Estado y a su relación inmediata con la ciudadanía igual, universalizada, considerando que el patriotismo cívico o republicano obvie el problema nacional. De otro, asumir la lógica argumental del nacionalismo, de las naciones como realidades orgánicas, naturales, casi biológicas, colectividades prepolíticas ajenas a la voluntad de los ciudadanos, homogéneas en el interior, netamente diferenciadas hacia el exterior, y dadas de una vez para siempre, según el respectivo mito de los orígenes" ${ }^{64}$.

Y es que, a pesar de su cercanía a las posiciones hegelianas -o justamente por ello-, el federalismo de Pi i Margall está en un punto clave más próximo a la idea kantiana de una escritura a priori de la historia (esto es, de una propuesta probable de futuro) que de todo intento romántico de retorno a no se sabe qué origen de los pueblos, sea mediante un supuesto examen científico racial o lingüístico, sea mediante una vaga ensoñación exaltada que despierte el entusiasmo entre quienes se sienten oprimidos (y oprimidos lo están, según $\mathrm{Pi}$, todos aquellos que están sometidos a un principio unitario, el cual es sólo posible "desde la acción de un poder extraño" ${ }^{65}$ ). Lo que Pi parece estar proponiendo, y da cuenta del interés actual que su postura suscita, es una suerte de proyecto sugestivo de vida en común, por decirlo con Ortega. ¿Y si en vez de volver una y otra vez a las raíces míticas de Cataluña, Castilla o Navarra, no se van estableciendo pactos, acuerdos entre esas diversas naciones (aunque Pi las llame a veces "regiones"), de acuerdo con lo que ellas mismas están ofreciendo ahora en sus múltiples relaciones con los pueblos vecinos (casi como si se hablara de biodiversidad política)? En vez de inventar una "comunidad imaginada", ¿por qué no "inventar", a través de pactos que, como ha recordado Villacañas, parecen recordar no tanto a las tradiciones catalanas cuanto a las ligas y comunidades medievales de Castilla ${ }^{66}$; por qué no inventar, digo, una nación por venir? Si España es la nación que no existe, pero sí se da en cambio la posibilidad de una propuesta (que obviamente habría de ser perfilada y matizada desde las necesidades geopolíticas actuales) de régimen político pac-

\footnotetext{
${ }^{64}$ R. Máiz, Estudio introductorio a: F. Pi i Margall, Las nacionalidades. Escritos y discursos sobre federalismo, Madrid, Akal, 2009, p. 50 ss.

${ }^{65}$ Las nacionalidades. Impr. y Libr. de Eduardo Martínez, Madrid, 1877, p. 201. Además de la recién citada edición de Akal, y de la de Biblioteca Nueva (2002), el texto de la $3^{\text {a }}$ ed. (1882) es hoy accesible en la Red: saavedrafajardo.um/es/.../501B17EID32840D0C12515DA003B7313?

${ }^{66}$ La idea federal en España op. cit., p. 141: "Pi y Margall, fijándose quizás más en la tradición castellana que en la catalano-aragonesa, entiende que entre la ciudad y el Estado lo que hay son ligas y comunidades de ciudades. De hecho, la deducción del poder federal, en su constructivismo, surge desde las necesidades de una efectiva relación económica y jurídica de ciudades entre sí, nexo que ninguna de ellas puede resolver".
} 
tista y de consenso que permita articularla desde comunidades históricamente conformadas y que, a la vez, posibilite su conexión orgánica con otras federaciones, para acabar formando una confederación de naciones europeas, ¿diríamos entonces que esta idea es simplemente una utopía inane? ¿Seguiremos oscilando una y otra vez entre el unitarismo abstracto y forzoso y el esencialismo plural de "pueblos milenarios"? Al fin, lo que Pi propone es que los estados centralizados unitarios (lo cual no se reduce desde luego a regímenes monárquicos) vayan evolucionando hacia articulaciones cada vez más complejas e interrelacionadas (una idea hegeliana donde las haya), al tomar ejemplo de los estados federales viables y existentes ya en la realidad ${ }^{67}$.

Y puesto que pacta sunt servanda, cabe resaltar la coherencia del pensamiento de Pi cuando éste, a propósito del pacto entre naciones, vuelve a tomar el problema de la pluralidad de "pequeñas naciones" integradas en la "gran Nación" de España, de Capmany, para arrimarlo más bien -pero ampliamente complejificado y enriquecidoa la propuesta de Marchena a Brissot sobre la idea federativa de la constitución de España ${ }^{68}$. Y lo hace de modo que es precisamente la crítica al organicismo esencialista lo que permite a Pi rechazar la idea de autodeterminación unilateral ${ }^{69}$. Pues si la fe-

${ }^{67}$ En este sentido se manifiesta actualmente José Antonio Ardanza, primer lehendakari de un gobierno vasco en democracia; así, en el documental de Julio Medem: La pelota vasca, la piel contra la piedra (2003), ofrece un pacto solidario al gobierno central: "Si ustedes aceptan que España no es una nación, sino [que] es un estado, pero que es plurinacional, y que el pacto entre naciones puede conformar una forma determinada de estado, podríamos empezar a entendernos. Porque España [si es] uninación, es Castilla ampliada" (el primer subr. es mío).

${ }^{68}$ En La verdadera patria, Pi se pregunta, retóricamente: “¿Tiene nuestra nación unidad de lengua? Hay en ella hasta seis dialectos del idioma latino y allá en el Norte una lengua madre [...] ¿Tiene España tampoco unidad de leyes? Diversas son las de Castilla, las de Vizcaya [...] Instituciones diversas hay también en Galicia [...] Ni tiene España unidad histórica. No hablemos de costumbres ni de razas. Aquí hay celtas, suevos, godos, árabes... ¿Obsta esto para que las regiones todas formen nación? Heterogéneas son todas las naciones de Europa. ¿Qué aconseja toda racional política? [...] que se organice el Estado sobre la base en que descansan todas las regiones federales" (Art. publ. en El Nuevo Régimen, 30 de septiembre de 1899; en: Articles, ed. de Gabriel Alomar, Barcelona, L'Anuari, 1908, p. 39). Adviértase cómo, a través de la idea fundamental del pacto, encuentra Pi un equilibrado punto medio entre la posición de Renan y la de Lord Acton, sin caer de un lado en el "voluntarismo decisionista" de supuestos individuos aislados, y del otro en el "esencialismo organicista". De este modo escapa también Pi de la concepción individualista y anarquizante (por lo menos en 1854, más cercana al Stirner de Der Einzige und sein Eigentum que a Proudhon, cuya Idée générale de la Révolution au XIX ${ }^{e}$ siècle, de 1851, conocía con seguridad). Cuando en 1863 aparece Du principe fédératif et de la nécessité de reconstituer le parti de la révolution, Pi está ya pasando del individualismo a la idea de sociedades naturales, base necesaria de un federalismo no liberal.

${ }^{69}$ No es necesario insistir al respecto en la máxima actualidad que presenta este rechazo por parte de Pi. Como es sabido, el gobierno actual de la Generalitat de Catalunya (formado por la coalición de los partidos CiU y ERC) pretende celebrar próximamente (aunque, todavía, sine die) un referéndum exclusivamente entre ciudadanos catalanes, sobre el deseo o no de éstos de seguir perteneciendo a España. 
deración tiene a la base un pacto, un contrato social entre iguales, hay que recordar entonces que los contratos: "no se disuelven ni rescinden por la [voluntad] de uno de sus contratantes. [...] Las confederaciones podrán disolverse por el mutuo consentimiento de los que la formaron, no por el de uno de sus pueblos" ${ }^{70}$.

Recuérdese, por lo demás, que hacia el comienzo de este ensayo habíamos mencionado la dificultad de portar dos o más identidades (étnica, cultural, política, por no hablar de la psíquica y aun de la ecológico-cósmica) para resolver el problema de los distintos organismos colectivos en que se ven insertos los individuos. Al respecto, la propuesta de Pi i Margall, a pesar de su buena voluntad, no puede ser del todo convincente. Y ello no tanto por estar basado en un difuso panteísmo pseudohegeliano, sino por su carácter fuertemente estático, adialéctico. Pues no se ve cómo pasar sin conflicto (el paso es el conflicto mismo, más bien) entre las tres patrias que él recomienda a sus paisanos catalanes: "Hay una patria de todos los hombres: la tierra. Hay una patria, que nos han hecho los siglos, de las mismas glorias y fatigas: la nación. Hay una patria que forman la misma lengua, las mismas leyes y los mismos usos y costumbres: la región. [...] Seamos catalanes, españoles, humanos"71.

Este carácter estático -de mera yuxtaposición de identidades- hizo del programa de Pi i Margall una promesa de futuro: sugestiva, sí, pero sin suficiente perfil y vigor como para ser llevada a cabo, y menos contra las fuerzas católico-monárquicas del momento (recuérdese la disolución de las Cortes españolas por el General Pavía el 3 de enero de 1874, que dio lugar a la Restauración en la persona de Alfonso XII de Borbón). Villacañas ha sabido resumir de forma certera lo irresoluble de las posiciones de Pi i Margall, y no sólo desde el punto de vista de la realización práctica. Así, afirma que, en Las nacionalidades (1877), Pi: "mantuvo una tensión entre la afirmación de una nacionalidad española y la tesis de que España jamás había tenido una forma política aceptable. En este caso, resultaba claro que la nacionalidad española era más bien un desideratum ${ }^{72}$. La primera consecuencia de la obra fue, en este sentido, que abrió la pregunta de cuál sería la verdadera nacionalidad deseable en el caso de España. Esta pregunta, cuando no fue contestada por praxis alguna, abrió la puerta al nacionalismo, como resulta evidente. Los catalanes respondieron que al menos Cataluña sí era un organismo nacional. España era, en el mejor de los casos, una hipótesis"73.

\footnotetext{
${ }^{70}$ Las Nacionalidades, op. cit., p. 261.

${ }^{71}$ La Questió de Catalunya: "Hi ha una patria per a tots els homes: la terra. Hi ha una patria que'ns han fet segles de les mateixes glòries i fatigues: la nació. Hi ha una patria que formen la mateixa llengua, les mateixes lleis i els mateixos usos i costums: la regió [...] Siguem catalans, espanyols, humans." En: Escrits i discursos (Trad. i Proleg de A. Rovira i Virgili), Barcelona, Societat Catalana d'Edicions, 1913, pp. 122-123.

${ }^{72}$ El subrayado es mío. Y yo añadiría por mi cuenta que, de algún modo, la nación española, la nación que no existe, sigue siendo por ello un desideratum. Pero no, espero, un simple pium desiderium.

${ }^{73}$ La idea federal en España, op. cit., p. 119 ss.
} 


\section{Conclusión: la España que no pudo ser}

Quizá no sea un mero azar el que la Constitución de 1876, resultado del golpe que disolvió la República y trajo a España la Restauración borbónica, haya estado vigente hasta el advenimiento de la democracia en España (justamente, cien años). Pues bien, puede decirse que, a partir de esa fecha, todo se fue radicalizando, por los dos extremos (los católicos-monárquicos de un lado, sin olvidar a los carlistas, y el creciente movimiento obrero, de raigambre anarquista). Ante estas tensiones, el Partido Republicano Democrático Federal, de Pi i Margall, a duras penas pudo seguir existiendo. En 1883, el Congrés de Catalunya Federalista había redactado un proyecto de constitución del Estado Catalán, dentro de la Federación Española, y que el Partido aprobó en la Asamblea de Zaragoza de junio de 1883, donde se acordó un proyecto de constitución federal que recogía básicamente las líneas elaboradas por el Congreso catalán.

Era el momento propicio para que comenzara a prender la llama de un nacionalismo catalán burgués cada vez más radicalizado, representado por una figura emblemática: Valentí Almirall, que ya en 1880 había convocado el Primer Congreso Catalanista (1880). En el Segundo Congreso (justamente en 1883, el mismo año en que todavía el Partido democrático republicano intentaba afianzarse) se debatió la conveniencia de las formaciones políticas españolas y de crear fuerzas propias para defender los intereses del país en las Cortes (repárese pues en que todavía no se planteaba, al incipiente nacionalismo, la idea radical de separación de España, que sólo advendrá, y con fuerza, a finales del siglo XX). Un paso más resuelto fue el dado por Almirall en 1885, al redactar un Memorial de Greuges (es decir: de agravios) que fue presentado a Alfonso XII. Se considera hoy este documento como la base de la síntesis ideológica de Enric Prat de la Riba. El federalismo era esa posibilidad para la nación española que podía evitar la caída sea en un autoritarismo identitario y uniformizador, sea en un fraccionamiento de las antiguas "nacionalidades" (y de otras "comunidades imaginadas" como Euskadi, a partir de la abolición de los fueros de las Provincias Vascongadas por Alfonso XII, en virtud de la Ley de 21 de julio de 1876: un año realmente fatídico).

¿Qué hacer? En 1894, Hermilio Olóriz redacta la Cartilla foral de Navarra, un breve "catecismo" en el que se propugna abiertamente la separación de Navarra respecto de España, y la vuelta a los Fueros de $1512^{74}$. Ese mismo año, Enrich Prat de

\footnotetext{
${ }^{74}$ Este catecismo laico figura como apéndice de La cuestión foral, de Hermilio Olóriz (1894). Hay reed. en: Tafalla, Txalaparta, 1994. Por su parte, en 1931, J. Elayo Zalduendo escribe un fogoso artículo: "Por la via pragmática a la meta ideal", en donde prueba que el navarrismo fue quien influyó en el catalanismo, y no al revés, gracias a Olóriz, ese "euskaro" que habría llegado al "Sinaí del navarrismo" (recogido en Navarra, una soberanía secuestrada: historia y periodismo, Tafalla, Txalaparta, 2004, p. 440).
} 
la Riba y Pere Muntanyola publican el Compendi de doctrina catalanista ${ }^{75}$, abiertamente inspirado en la Cartilla. Ya había dicho poco antes Antonio Cánovas del Castillo: "Son españoles los que no pueden ser otra cosa"76.

En 1898, Joaquín Costa expone en el segundo tomo de su Colectivismo Agrario en España lo que viene a ser una amplia historia económica de los sistemas de propiedad, las formas de explotación de la tierra, el control sobre el agua, etc. Todo ello, para acabar de una buena vez, en España, con un caduco sistema parlamentario sin electores (por su parte, Donoso Cortés había tildado a los diputados en Cortes de "Clase discutidora"); según el rudo político regeneracionista, ese supuesto poder constituyente no estaría formado sino por una "oligarquía de notables". Su propuesta: "Escuela, despensa y siete llaves para el sepulcro del Cid".

Pero todo fue en vano: en 1898 estalló la Guerra contra los Estados Unidos (a la que, por cierto, se opuso gallardamente el anciano Pi i Margall), lo cual acarreó la pérdida de Cuba, Puerto Rico y Filipinas. Y con esa pérdida volvió a plantearse, aún con mayor fuerza, la pregunta por el "ser" de España con que comenzamos el ensayo, y a darle vueltas ad nauseam a la supuesta función que la pobre y esquilmada Castilla habría jugado en todo ello, convirtiéndola de nuevo en la gran promesa de aglutinación, si es que no de asimilación. En torno a si Castilla deshizo a España, si se deshizo en España o si fue España la que deshizo a Castilla (graves cuestiones, a fé) se pelearon, agitados, nuestros intelectuales: Américo Castro, Claudio Sánchez Albornoz, José Ortega y Gasset... hasta que el "glorioso" Alzamiento Nacional, que comenzara el 18 de julio de 1936, pusiera firme de nuevo a la Nación (como que los rebeldes gustaron de llamarse a sí mismos "nacionales") $)^{77}$. Pocos años después, figuras hoy ya felizmente olvidadas, como la de José María Mendoza Guinea, en su calidad de Jefe Nacional del Servicio Español del Magisterio, publicaban, volumen tras volumen, el manual de la asignatura obligatoria: Formación del Espíritu Nacional ${ }^{78}$. Era la versión más extrema del rancio organicismo esencialista contra el que habían luchado Marchena, Pi i Margall, Ortega y tantos otros. En nuestros días, la rama moderada del PSOE, abanderando un republicanismo de manual ${ }^{79}$, ha propuesto para remediar los males de España una asignatura denominada: "Educación para la

\footnotetext{
${ }^{75}$ Editado en: Sabadell, Impr. de La Renaixensa, 1894.

${ }^{76}$ Según El porqué de los dichos, de José María Iribarren (1955; reed. en: Barcelona, Ariel, 2013), se trata una frase, pronunciada en privado, de Cánovas a Manuel Alonso Martínez, a raíz de la dificultad de recoger en la Constitución de 1876 una definición relativa a los "españoles".

${ }^{77}$ Sobre las bases ideológicas del Movimiento, remito a mi Teofranquismo. Una aproximación a la crítica de la teología política en los años sombríos. En: V. Rocco \& R. Navarrete (eds.), Teología y teonomía de la política, Madrid, Abada, 2012, pp. 147-217.

${ }_{78}^{78}$ Madrid, Editorial Xalco, 1957-1958 (Cursos I-VI).

79 Según parece, el libro de cabecera del expresidente Rodríguez Zapatero habría sido: Republicanismo, de Philip Petit, Barcelona, Paidós, 1999.
} 
ciudadanía”. Algo que el actual gobierno del Partido Popular se ha apresurado a suprimir del programa de enseñanza, favoreciendo en cambio la obligatoriedad de la asignatura de Religión, sustituible en todo caso por otra sobre "Valores morales".

¿No hay esperanza para esta Nación que no existe? Sí, nos dicen quienes saben: parece haberla. La misma por la que John Stuart Mill se consolaba respecto a los estados fallidos de su época. La misma de Ernest Renan. La misma que la defendida por Ortega. La misma que en el Eurobarómetro de la primavera de 2007 (antes de que el mal viento de la crisis arramblara con todo) apoyaba el 75\% de los españoles consultados. La consigna reza: a la salvación por Europa ${ }^{80}$. Precaria solución, ésta, que pretende superar los "males de la patria" pidiendo que un "poder superior" les ponga remedio.

Deberemos volver a leer con cuidado a Pi i Margall. Y también, desde luego, a Cicerón:

Nostris enim vitiis, non casu aliquo rem publicam verbo retinemus; re ipsa vero iam pridem amisimus ${ }^{81}$.

\footnotetext{
${ }^{80}$ Por cierto, eso es lo que propugnan igualmente los independentistas catalanes, mientras que los partidos abertzales del País Vasco, una vez caído el maoísmo y "redescubierta" Albania, siguen sin saber muy bien a quién acudir.

81 "Por nuestros vicios, no por mala suerte, mantenemos de palabra a la república [la cosa pública]; pero, en verdad, hace mucho tiempo que hemos perdido la cosa misma." Cicerón, De re publica V. 1,2.
} 